\title{
The Overdue Case Against Sex-Segregated Bathrooms
}

\author{
Laura Portuondo ${ }^{\dagger}$
}

INTRODUCTION

I. THE UNREVEALING HISTORY OF SEX-SEGREGATED BATHROOMS

A. Origins .............................................................................. 471

B. Sex-Segregated Bathrooms and the ERA Debates ......................476

II. THE JURISPRUDENCE OF SEX-SEGREGATED BATHROOMS ........................482

A. The Interest in Accommodating Biological Differences ................483

B. The Interest in Protecting Privacy...............................................485

C. The Interest in Protecting Women's Safety ..................................491

III. THE Legal CASE AgaInST SEX-Segregated BATHRoOMS ...................497

A. The Intermediate Scrutiny Standard ..........................................497

B. Applying Intermediate Scrutiny to the Judicially Asserted

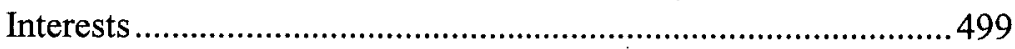

1. Accommodating Biological Differences.............................499

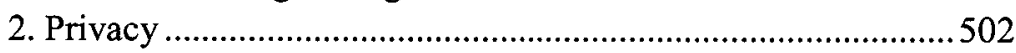

3. Safety .......................................................................... 510

IV. The Normative Case Against SeX-Segregated Bathrooms ..........514

A. When Separate May Be Equal: The Subordination Distinction .....514

B. Overcoming the Privacy Objection: Sex-Segregated Bathrooms

Perpetuate Harmful Stereotypes ...........................................517

C. Overcoming the Safety Objection: Sex-Segregated Bathrooms

Perpetuate Dangers for Women ...............................................521

$\dagger \quad$ Yale Law School, J.D., expected 2018; Yale University, B.A., 2014. I am grateful and indebted to Professor Cary Franklin for her encouragement, edifying conversation, incisive feedback, and generous support through every stage of the writing process. I am also grateful to Professor Reva Siegel for helping with this Note's inception and for continuously inspiring my intellectual work through her own. I am grateful to the editors of the Yale Journal of Law and Feminism, particularly Emma Thurber Stone and Elise Wander, for their careful edits and suggestions. Finally, I would like to thank Christina Ford, Cody Taylor Knapp, Anthony Sampson, Helen White, and countless others for illuminating conversations about the ideas in this Note. 


\section{INTRODUCTION}

In 2002, Krystal Etsitty, a transgender woman, was fired from her job as a bus driver for her "intent to use women's public restrooms" along her route. ${ }^{1}$ In 2007, she lost an employment discrimination suit because, the Tenth Circuit held, her employer's "concern" that "the use of women's public restrooms by a biological male could result in liability... constitute[d] a legitimate, nondiscriminatory reason" for termination. ${ }^{2}$ According to the Tenth Circuit, Etsitty was fired not because of her employer's discriminatory beliefs but instead because of her employer's-and potential female litigants'- "legitimate" commitment to sex-segregated bathrooms. ${ }^{3}$ Etsitty v. Utah Transit Authority highlights the obvious but often-overlooked reality that sex-segregated bathrooms are a but-for cause of the current transgender bathroom controversy. More importantly, the case illustrates a widespread assumption that sex-based bathroom segregation is not-and should not be-subject to legal change.

Despite a recent rise in litigation surrounding transgender restroom access, sex segregation of bathrooms has never been the subject of direct legal challenge. Transgender litigants suing for bathroom access have thus far challenged the discriminatory enforcement of sex-segregation rather than the sex-segregation itself. ${ }^{4}$ Although LGBTQ activists have done significant and important legal advocacy challenging sex-segregated spaces, ${ }^{5}$ the sex-segregation of bathrooms

1. Etsitty v. Utah Transit Auth., 502 F.3d 1215, 1224 (10th Cir. 2007).

2. Id.

3. Id. at 1225 .

4. In an appeal to the Fourth Circuit, for example, transgender plaintiff Gavin Grimm was careful to distance himself from any challenges to sex-segregation, urging that "the question is not whether providing separate restrooms to boys and girls as a general matter serves the governmental interest in student privacy." Brief of Plaintiff-Appellant at 39, G.G. ex rel. Grimm v. Gloucester Cty. Sch. Bd., 822 F.3d 709, 734 (4th Cir. 2016) (No. 15-2056). Indeed, the brief even conceded that sexsegregated restrooms may be justified. Id. at 41 ("' $[\mathrm{P}]$ rivacy interests may justify separate but truly equal and nonstigmatizing restroom facilities for boys and girls ....").

5. This includes sports teams, identification laws, and other spheres. For one example of advocacy directly challenging enforcement of gender binaries, see Zzyym v. Kerry, 220 F. Supp. 3d 1106 (D. Colo. 2016), in which intersex activist Dana Zzyym along with Lambda Legal secured a favorable ruling from a district court after they challenged the State Department practice of requiring a binary "female" or "male" designation on passports. Transgender and gender nonconforming activists have also advocated for transgender access to binary spaces in other spheres, even if they have not directly challenged these binary spaces. For an introduction to the groundbreaking work many LGBTQ organizations have done to advocate for legal and social reform in the fraught sphere of gendered sports teams, see Helen J. Carrol, The Present Explosion of LGBT Sports, 34 LAW \& INEQ. 499 (2016). 
remains outside of the scope of constitutional concern for many legal advocates working for gender and sexual justice. ${ }^{6}$

This fact may be surprising, given that feminists have tirelessly targeted instances of overt sex-based classification in our law for much of the last fifty years. Conservative opponents of transgender bathroom access would likely attribute this inconsistency to a desire on the part of feminists to preserve the benefits women receive from segregation. Opponents of liberalized bathroom laws tend not to frame their resistance as a desire to discriminate against gendernonconforming people, but rather as a desire to protect women from men (or transgender women) who might take advantage of such liberalization. ${ }^{7}$ Perhaps, these opponents suggest, feminists have not sought to integrate bathrooms because they similarly believe that strict segregation protects women's privacy and safety. ${ }^{8}$

Such an explanation, however, has the unfortunate effect of pitting the rights of transgender individuals against the rights of cisgender ${ }^{9}$ women. ${ }^{10}$ While there

6. For a description of the many tactics and considerations that transgender and other activists have explored for addressing the harms of sex-segregated bathrooms and sex segregation more generally, see Alex Faktor, Access and Exclusion, 7 J. HuM. SECURITY 10, 16-19 (2011); id. at 16-17 ("There are diverse routes of addressing and approaching this issue. The aforementioned matrices of power [which perpetuate sex-segregated bathrooms] present-or rather, necessitate-multiple levels of activism. Some strategies include legal routes, grassroots activism, changing social attitudes, and various hybrids.").

7. For an example of the safety-based component of this argument, see Kaeley Triller Haver, $A$ Rape Survivor Speaks Out Against Transgender Bathrooms, FEDERALIST, Nov. 23, 2015, http:// thefederalist.com/2015/11/23/a-rape-survivor-speaks-out-about-transgender-bathrooms [https:// perma.cc/JJJ8-WZTM] (describing how cisgender male predators will take advantage of liberal bathroom laws to sexually assault women). For an example of the privacy-based component of this argument, see Fr. Mark Hodges, Proposed Bathroom Bill Will Keep 'Transgender' Men Out of Girls' Bathrooms in Texas, LIFE SITE, Jan. 9, 2017, https://www.lifesitenews.com/news/publicreacts-to-texas-proposed-bathroom-privacy-law-with-praise-protests [https://perma.cc/38N6SJTV] (describing the "Women's Privacy Act," a bill proposed by the Republican Lieutenant Governor, which would require people to use the restroom that matches their "biological sex" in order to protect women's privacy). This essay will discuss these arguments at length infra Part II.C.

8. Conservative media outlets have been eager to highlight that opposition to transgender bathroom access is an issue over which feminists and conservative groups can unite. See Christians \& Feminists Team Up To Fight Transgender Bathroom Mandate, FOX NEWS INSIDER, Feb. 7, 2017, http://insider.foxnews.com/2017/02/07/tucker-carlson-tonight-christians-feminists-team-fighttransgender-bathroom-mandate [https://perma.cc/7GFD-W6V9].

9. The term "cisgender" refers to individuals whose gender identity corresponds with the sex they had or were identified as having at birth.

10. This dichotomy between transgender people and women is misleading, first and foremost because it imagines that transgender women do not exist. Because the history of sex-segregated restrooms is rooted in the ideology of sexual difference, and because this Note intends to engage meaningfully with the arguments of skeptical readers, it will often refer to "men" and "women" as though they are binary and biologically distinct. However, it is equally important to remember that these categories are neither dichotomous nor exhaustive of possible gender identities. For a more complete introduction to gender terminology than can be attempted here, see SUSAN STRYKER, TRANSGENDER HISTORY 7-24 (2008) 
have been both past ${ }^{11}$ and present ${ }^{12}$ tensions between self-proclaimed women's activists and transgender activists, there is no reason to assume bathrooms need be a site of such conflict. ${ }^{13}$ LGBTQ advocates have traditionally advocated strongly against sexual assault and gender injustice, and feminist advocacy groups across the country have largely voiced support for transgender bathroom access. ${ }^{14}$ This Note will argue, in fact, that a basic premise of women-protective opposition to liberalized bathroom access, namely that sex-segregated bathrooms benefit women in general, is fundamentally flawed. It is time that all those interested in the rights of women recognize the harms-of constitutional proportions-that sex-segregated facilities enact.

This Note helps untangle the perceived tension between transgender bathroom access and women's rights by examining the historical, legal, and

11. See JOANNE MEYEROWITZ, How SEX CHANGED: A HiSTORY OF TRANSSEXUALITY IN THE UNITED STATES 258 (2002) (describing many feminists' "overt rejection of transsexuals" in the 1970s); STRYKER, supra note 10 , at 94 (relating how in the 1970s "the transgender political movement lost its alliances with gay and feminist communities in ways that did not begin to be repaired until the early 1990s, and that, in many ways, have yet to be fully overcome").

12. Although a full examination of the skepticism-and often outright hostility--some contemporary radical feminists have expressed toward transgender identity is beyond the scope of this Note, readers interested in this debate will find a careful exploration of the issue in PATRICIA ELLIOT, DEBATES IN TRANSGENDER, QUEER, AND FEMINIST THEORY: CONTESTED SITES (2010). Elliot describes rifts and sources of tension among various feminist, queer, and transgender theorists while ultimately maintaining that "despite sustained efforts . .. to pit feminists against transsexuals . . alliances [between cisgender women] with transsexuals are possible, even necessary, if we are to live up to our own political commitments." Id. at 11-12. For a brief introduction to this debate, see also Michelle Goldberg, What Is a Woman?, NEW YORKER, Aug. 4, 2014, http://www.newyorker .com/magazine/2014/08/04/woman-2 [https://perma.cc/MM42-LW3R] (describing contemporary tensions between "radical feminists" and transgender activists).

13. While the Right's women-protective arguments may be sincere, they should also be taken with a degree of skepticism. Conservative movements have appealed to women-protective arguments in the past, for example, as a politically strategic means of making their anti-abortion policies more palatable to the public, even when there was no evidence that these policies advanced the health and safety of women. See Reva B. Siegel, The Right's Reasons: Constitutional Conflict and the Spread of Woman-Protective Antiabortion Argument, 57 DUKE L.J. 1641 (2008) (describing the Right's shift to women-protective arguments as Americans became less receptive to their fetal-protective arguments). Even the Supreme Court has looked with increasing skepticism at these womanprotective arguments in the abortion context, suggesting skepticism may be warranted in the bathroom context as well. See, e.g., Whole Woman's Health v. Hellerstedt, 136 S. Ct. 2292 (2016) (striking down a Texas law regulating abortion clinics because there was no evidence that it actually protected women's health and some evidence that it instead undermined women's health).

14. The massive backlash from women's organizations against President Trump's rollback of the Obama Administration's trans-inclusive Title IX guidance, which allowed transgender students to use bathrooms conforming with their gender identity, illustrates this point. See, e.g., Press Release, Nat'l Org. for Women, Shame on Donald Trump for Rolling Back Rights for Transgender Students, Feb. 23, 2017, http://now.org/media-center/press-release/shame-on-donald-trump-for-rolling-backrights-for-transgender-students [https://perma.cc/DX26-LARJ]; Press Release, Am. Civil Liberties Union, Press Release, ACLU Statement on Revoking of Title IX Guidance for Transgender Students \& Impact on Gavin Grimm Supreme Court Case, Feb. 22, 2017, https:/www.aclu.org/news/aclustatement-revoking-title-ix-guidance-transgender-students-impact-gavin-grimm-supreme-court [https://perma.cc/H9A4-ZK9B]; Press Release, Nat'] Women's Law Ctr., NWLC Reacts to Administration's Removal of Guidance on Transgender Students, Feb. 22, 2017, https://nwlc.org /press-releases/nwlc-reacts-to-administrations-removal-of-guidance-on-transgender-students [https://perma.cc/3KNG-2BW7]. 
normative case against sex-segregated bathrooms. ${ }^{15}$ While scholars have addressed pieces of this question, ${ }^{16}$ this Note is novel in its integrated examination of these three essential tools for evaluating the continued appropriateness of sex-segregated bathrooms. This Note intends to engage generously and sincerely with the most compelling arguments that sexsegregated bathrooms are justifiable, and even important, spaces. ${ }^{17}$

Part I will address two important aspects of the history of sex-segregated bathrooms: first, their origins, and second, the historical lack of high-profile feminist opposition to them. Evidence suggests that sex-segregation originates from outdated and harmful stereotypes about the nature and role of women. As such, the original rationales for sex-segregated bathrooms are unlikely to serve as persuasive legal or normative justifications for continued segregation today. Part I next examines feminists' historical lack of opposition to sex-segregated restrooms, with a focus on debates surrounding the Equal Rights Amendment (ERA) ${ }^{18}$ Relying on the work of historians of the ERA,${ }^{19}$ this Note demonstrates that feminist "support" was instead a careful political strategy that tells us little about how feminists actually felt about bathrooms or how they should think about them today.

After this historical examination, Part II demonstrates that legal sources similarly fail to provide adequate justification for sex-segregated bathrooms. It will survey judicial opinions touching the matter, highlighting a rich and underutilized body of legal reasoning. While sex-based segregation has not been directly challenged in court, transgender bathroom litigation as well as Title VII cases related to sex-segregated bathrooms have required judges to address what

15. Ruth Colker's recent article Public Restrooms: Flipping the Default Rules, 78 OHIO ST. L.J. 145 (2017), employs a similar framework for evaluating the constitutional appropriateness of sexsegregated restrooms. While there are similarities between our pieces, this Note aims to engage more fully with potential objections by defenders of sex-segregated bathrooms. In terms of legal analysis, this Note draws on a larger body of case law than Professor Colker's; hers focuses primarily on Supreme Court sex discrimination cases and transgender access litigation. This Note examines a fairly large body of Title VII case law that Professor Colker does not address.

16. See, e.g., Terry S. Kogan, Sex-Separation in Public Restrooms: Law, Architecture, and Gender, 14 MICH. J. GENDER \& L. 1 (2007) (exploring the history of sex-segregated restrooms, with less attention to legal and normative arguments behind the institutions); Christine Overall, Public Toilets: Sex Segregation Revisited, 12 ETHICS \& ENV'T 71 (2007) (exploring the normative arguments around sex-segregated bathrooms, with less attention to historical and legal arguments).

17. Christine Overall's Public Toilets: Sex Segregation Revisited, supra note 16, takes the other side seriously. This Note builds on her theory by grounding it in and integrating it with real-world historical and legal evidence.

18. While other authors have touched on the ERA debates as a means of understanding the history of sex segregation, their analyses miss this vital contour of ERA supporters' lack of opposition to sexsegregated bathrooms. Those authors unnecessarily imply that feminists may have supported sexsegregated bathrooms during this time. See Colker, supra note 15, at 159; Kogan, supra note 16, at 17.

19. This Note primarily relies on JANE J. MANSBRIDGE, WHY WE LOST THE ERA (1986), but it also draws from DAVID E. KYVIG, EXPLICIT AND AUTHENTIC ACTS: AMENDING THE U.S. CONSTITUTION 1776-2015, 394 425 (2016) and DONALD G. MATHEWS \& SHERRON DE HART, SEX, GENDER AND THE POLITICS OF THE ERA: A STATE AND THE NATION (1992). 
interests, if any, sex-segregated bathrooms serve. Judges assert three primary interests to support sex-segregated facilities: accommodation of biological needs, protection of privacy, and protection of women's safety. Part II will explore these asserted interests in detail, and in the best possible light, before subjecting them to constitutional scrutiny.

Part III will demonstrate that none of the interests marshalled in support of sex-segregated bathrooms stands up to intermediate scrutiny, primarily because the sex-specific nature of these interests undercuts their importance. It concludes that even if these interests were important, sex-segregated bathrooms would do little to serve them.

Finally, Part IV develops the normative case against sex-segregated bathrooms. While principles of constitutional sex-discrimination analysis demonstrate that sex-segregated bathrooms stand on shaky legal ground, some self-proclaimed feminists may object that a legal challenge-and perhaps even heightened scrutiny-is inappropriate because sex-segregated bathrooms benefit women, particularly cisgender women. Drawing on the work of social scientists, feminist theorists, and other scholars, ${ }^{20}$ this Part will argue that sex-segregated bathrooms are in fact normatively undesirable, harming women far more than they benefit them. Sex-segregated bathrooms perpetuate harmful stereotypes about women and subordinate women's needs. As such, all interested in advancing the rights of women should treat them as a proper and desirable target of constitutional challenge.

\section{THE UNREVEALING HISTORY OF SEX-SEGREGATED BATHROOMS}

In his dissent to the Fourth Circuit's opinion in G.G. v. Gloucester County, Judge Paul Niemeyer characterized the decision, which allowed a transgender student to access bathrooms conforming with his gender identity, as historically aberrant. "Across societies and throughout history," he urged, "it has been commonplace and universally accepted to separate public restrooms ... on the basis of biological sex."21 There is a good deal of truth to this claim. The claim also significantly oversimplifies the matter. While a long and relatively unchallenged tradition of sex-segregated bathrooms in the United States exists, invoking it as evidence to support continued segregation fails to account for

20. This Note relies most heavily on a collection of essays contained in LADIES AND GENTS: PUBLIC TOILETS AND GENDER (Olga Gershenson \& Barbara Penner eds., 2009). It also relies on Kathryn H. Anthony \& Meghan Dufresne, Potty Parity in Perspective: Gender and Family Issues in Planning and Designing Public Restrooms, 21 J. PLAN. LIT. 267 (2007); Spencer E. Cahill et al., Meanwhile Backstage: "Public Bathrooms and the Interaction Order," 14 URBAN LIFE 33 (1985); and Patricia Cooper \& Ruth Oldenziel, Cherished Classifications: Bathrooms and the Construction of Gender/Race on the Pennsylvania Railroad During World War II, 25 FEMINIST STUD. 7 (1999).

21. G.G., 822 F.3d at 734 (Niemeyer, J., concurring in part and dissenting in part), cert. granted in part, 137 S. Ct. 369 (2016), vacated and remanded, 137 S. Ct. 1239 (2017). 
important contours of the history. This Part will explore two of these contours, demonstrating how the legal and social history of sex-segregated bathrooms speaks less clearly in support of segregation than it initially appears.

While it is true that sex-segregated bathrooms have never been seriously challenged in the United States, this does not mean that sex-segregated bathrooms are an innocuous or neutral feature of American architecture. First, an examination of sex-segregated bathrooms' origins reveals that they emerged from nineteenth-century stereotypes about the capacities and role of women. Second, a study of the ERA debates-a time during which bathrooms were an unusually prevalent topic of conversation-helps reveal why, despite these dubious origins, feminists have not historically opposed sex-segregated bathrooms. Feminists, it seems, have simply not considered this form of segregation to be subordinating or a worthwhile locus of activism, at least outside of a few clearly discriminatory settings. Without significant resistance from feminists or others-until the advent of recent transgender and gendernonconforming activism-sex-segregated bathrooms have remained largely uncontroversial.

\section{A. Origins}

Judge Niemeyer suggests that sex-segregated bathrooms have been universally accepted "[a]cross societies and throughout history," but this is an overstatement. Sex-segregated restrooms have not been a feature of all social and legal landscapes since time immemorial. Rather, they are a modern, particularly Western European phenomenon. ${ }^{22}$ Public restrooms did not exist until the nineteenth century, when they emerged as part of larger sanitary and urban reform efforts. Although public restrooms appeared in some places by the $1820 \mathrm{~s}$, their first popular debut occurred at the Paris Great Exhibition of $1851 .{ }^{23}$ Even then, restrooms were not ubiquitous in many cities until decades later. In the United States, public restrooms were not a common feature of cityscapes until well after the 1870s, when public "comfort stations" briefly became a focus of public health reform. ${ }^{24}$ Indeed, by 1896 fewer than one-third of Americans lived in towns with sewage systems, let alone publicly provided toilets. ${ }^{25}$

22. Olga Gershenson \& Barbara Penner, Introduction: The Private Life of Public Conveniences, in LADIES AND GeNTS: Public TOILETS AND GENDER 4-5 (Olga Gershenson \& Barbara Penner, eds., 2009).

23. Id. at 5 .

24. See Peter C. Baldwin, Public Privacy: Restrooms in American Cities, 1869-1932, 48 J. SOC. HIST. 264, 265 (2014); Terry S. Kogan, supra note 16, at 37.

25. Samuel W. abbott, The Past and Present Condition of Public Hygiene and State MEDICINE IN THE UNITED STATES, in MONOGRAPHS ON AMERICAN SOCIAL ECONOMICS 40 (Herbert B. Adams \& Richard Waterman, Jr., eds., 1900), https://babel.hathitrust.org/cgi/pt?id=mdp .39015037507848 [https://perma.cc/2NSF-7HCR]; see also Kogan, supra note 16, at 37 n.158. 
Even as public restrooms became more common, however, lawmakers designated them as almost exclusively for men. ${ }^{26}$ In cases where restrooms were provided for women, they were generally so inadequate as to be unusable. ${ }^{27}$ The broad failure to provide women with public restrooms reflected and perpetuated a prominent set of sex-based stereotypes, namely those embodied in the nineteenth-century ideology of separate spheres. ${ }^{28}$ This ideology cast men as breadwinners and proper occupants of public life, while it cast women as distinctly domestic, naturally suited to rearing children and maintaining the home. ${ }^{29}$ Justice Bradley's 1873 concurrence in Bradwell v. Illinois, which upheld a state's denial of a law license to a woman on the basis of her sex, memorializes this ideology in American jurisprudence:

[C]ivil law, as well as nature herself, has always recognized a wide difference in the respective spheres and destinies of man and woman. Man is, or should be, woman's protector and defender.... The paramount destiny and mission of woman are to fulfil the noble and benign offices of wife and mother. ${ }^{30}$

Under this ideology, the provision of public restrooms for women seemed not only unnecessary, but also threatening. As Barbara Penner and Olga Gershenson have suggested, "[s]anctioning the woman's lavatory effectively sanctioned the female presence in the streets, thus violating middle-class decorum and ideals of women as static and domestic." ${ }^{\prime 31}$ By providing sufficient public restrooms for men and not women, policymakers significantly limited

26. Baldwin, supra note 24, at 266 (describing how "many nineteenth-century facilities did not accommodate women" and how sanitary reform efforts "focus[ed] on men"); Gershenson \& Penner, supra note 22 , at 5 ("[T] he vast majority of public facilities were for men only . ..."). Affluent women contributed to this disparity by "vot[ing] every[ ]day with their seats, preferring the consumer model of privacy in department store restrooms to the disturbingly messy egalitarian municipal facilities." See Baldwin, supra note 24, at 266.

27. See Baldwin, supra note 24, at 268-69 (describing an early women's restroom in the vicinity of Astor Place, which served 1,000 men and only 25 women per day, in part because the stalls were too large for affluent women's skirts and the anteroom was "too small to effectively screen the interior").

28. Gershenson \& Penner, supra note 22, at 4-5 (" $[\mathrm{S}]$ ex-segregated lavatories were . . bound up with ... the gendered ideology of the separate spheres.").

29. See, e.g., Baldwin, supra note 24, at 265-66 ("Americans persisted in speaking as if women's natural place were the secluded domestic interior, and their mental world encompassed private matters of emotion and caregiving. Men were said to control the public spaces of the city, and the public life of business, work and politics."); Frances Oisen, The Family and the Market: A Study of Ideology and Legal Reform, 96 HARV. L. REV. 1497, 1499-1501 (1983) (describing the separate spheres ideology and its interaction with legal reform and economic thought); see generally Barbara Weiter, The Cult of True Womanhood: 1820-1860, 18 AM. Q. 151 (1966) (describing at length Victorian conceptions of the proper roles and attributes of women, including their relegation to the domestic sphere).

30. Bradwell v. Illinois, 83 U.S. 130, 141 (1872).

31. Gershenson \& Penner, supra note 22, at 5. 
women's mobility in cities, creating a biological barrier to straying too far from home. ${ }^{32}$ The power of absent or inadequate women's restrooms to enforce gender roles appears starkly in the more modern example of the United States Senate, which lacked a women's restroom until the early 1990s. Before then, there was only one restroom outside the Senate chamber, which was labeled "Senators Only" and reserved exclusively for men. ${ }^{33}$ This no doubt conveyed a message about what sex a Senator was expected to be.

Although a shortage of accessible restrooms clearly harmed women, and women activists worked to secure their broader provision, ${ }^{34}$ the emergence of women's-only restrooms should not be hailed as an unmitigated feminist victory. It is significant that policymakers chose to increase women's access by building more separate restrooms for women rather than by simply integrating existing men's rooms. While sex-segregated restrooms may seem like an obvious choice today, converting men's rooms into unisex restrooms could have been an equally, if not more, efficient solution. Although there is limited scholarship on the legal origins of sex-segregated bathrooms, ${ }^{35}$ evidence suggests that the choice to systematically sex-segregate restrooms was a product of deeply held stereotypes about the capacities and roles of women. ${ }^{36}$

In his history of sex-segregated restrooms, for example, law professor Terry Kogan draws a link between sex-based stereotypes and the emergence of sexsegregated bathrooms in the American workplace. Despite the separate-spheres ideology that relegated women to the home, women at the end of the nineteenth century increasingly emerged into the public sphere as workers and activists. ${ }^{37}$ Faced with these newly public women, social theorists, scientists, and policymakers did not choose to reassess their stereotypes about women's domesticity. Rather, they "reconcile[d] the inherent conflict" by "discover[ing] the weakness of women." 38 Some scientists-under a guise of clinical

32. While private establishments such as department stores and hotels sometimes provided restrooms for women where municipalities would not, these restrooms similarly reinforced the notion that women belonged in the domestic sphere. Whereas men's rooms were largely functional in these establishments, women's rooms were elaborate "faux-domestic spaces" intended to make women feel at home, even in public. Baldwin, supra note 24, at 272.

33. Kathryn H. Anthony \& Meghan Dufresne, Potty Parity in Perspective: Gender and Family Issues in Planning and Designing Public Restrooms, 21 J. PLAN. LITERATURE 267, 271 (2007).

34. Baldwin, supra note 24 , at 274-76.

35. Judith Plaskow, Foreword, in LADIES AND GENTS: PubliC TOILETS AND GENDER viii (Olga Gershenson \& Barbara Penner eds., 2009) (describing the relative dearth of academic and public discussion of public restrooms).

36. "Despite common intuitions, the historical and social justifications for the ubiquitous practice of separating public restrooms by sex were based not on a gender-neutral policy related to simple anatomical differences between men and women. Rather its origins were deeply bound up with early nineteenth century moral ideology concerning the appropriate role and place for women in society." Kogan, supra note 16 , at 55 .

37. Id. at $21-23$.

38. Id at $24-25$. 
neutrality — began to study and postulate inherent differences between men and women. Such "scientific" findings reinforced and replicated beliefs that women belonged in the home by casting them as particularly vulnerable when in the public sphere. ${ }^{39}$

These findings convinced legislators that women needed extra protection, particularly in public spaces such as the workplace. ${ }^{40}$ Legislators thus began to pass protective legislation, often limiting the conditions under which women could work. In Muller v. Oregon, for example, the court upheld a law limiting the length of women's workdays based on "abundant testimony of the medical fraternity" indicating that "woman's physical structure and the performance of maternal functions place her at a disadvantage" in the workplace. ${ }^{41}$ The Court, citing recent science, cast women as inherently weaker than men, emphasized their role as mothers, and "reinforce[d] sexual stereotypes" that served to "undermine the quality of women's lives." 42

Sex-segregated bathrooms find their legal origins in a similar kind of stereotype-enforcing protective legislation. ${ }^{43}$ The first American laws mandating sex-segregated bathrooms were added as amendments to legislation creating special protections for women and children workers. ${ }^{44}$ These laws, with names such as "An Act to Protect the Lives and Health and Morals of Women and Minor Workers," were not gender-neutral but aimed to protect women specifically. ${ }^{45}$ Legislators hoped separate restrooms would accommodate women's "increased susceptibility to dizziness, fainting, and hysteria" and pròtect their modesty. ${ }^{46}$ Such clearly stereotypical reasoning suggests that sex-segregated bathrooms originated from outdated conceptions about the role and capacities of women.

Although many modern sex-segregating bathroom laws are not related to employment, ${ }^{47}$ the reliance of legislators on sex-based stereotypes in the labor

39. For a discussion of a similar campaign by scientists to construct gendered difference and reinforce "separate spheres" in the abortion context, see Reva Siegel, Reasoning from the Body: A Historical Perspective on Abortion Regulation and Questions of Equal Protection, 44 STAN. L. REv. 261, 280319, 322-23 (1992) [hereinafter Siegel, Reasoning from the Body].

40. Kogan, supra note 16 , at 27.

41. 208 U.S. 412,421 (1908). The Court was particularly concerned with the impact that unlimited workdays might have on women's ability to perform their proper domestic role of raising and teaching the next generation: "[A]s healthy mothers are essential to vigorous offspring, the physical well-being of woman becomes an object of public interest and care in order to preserve the strength and vigor of the race." Id. The gendered nature of the Court's protectionist sentiments is particularly highlighted by its rejection of a maximum-hours law for male bakers only three years earlier in Lochner v. New York, 198 U.S. 45 (1905).

42. Olsen, supra note 29 , at 1555.

43. Kogan, supra note 16 , at 15-16.

44. Id.

45. Brief of Professor Terry S. Kogan as Amicus Curiae in Support of Respondent at 12, Gloucester Cty. Sch. Bd. v. G.G. ex rel. Grimm, 137 S. Ct. 369 (2016) (No. 16-273).

46. Id. at $12-13$.

47. For an extensive list of state laws mandating sex-segregation of non-employment spaces, see David S. Cohen, The Stubborn Persistence of Sex Segregation, 20 COLUM. J. GENDER \& L. 51, 82 n.120 
context suggests they relied on them in others. ${ }^{48} \mathrm{~A}$ number of state laws, for example, require the provision of sex-segregated bathrooms only if women are "present" or "employed," relying on a stereotypical notion that public and work spaces are male by default. ${ }^{49}$ Further, it is telling that sex-segregated restrooms emerged simultaneously with sex-segregated spaces that have been long since integrated, such as libraries, railroad cars, and salons. ${ }^{50}$ These other instances of sex segregation have disappeared largely due to the advocacy of women who recognized that their segregation and "[e]xclusion from public accommodations" had "helped to write male supremacy and heteronormativity onto the social, physical, and economic landscape of U.S. cities." 51

The Supreme Court has also increasingly recognized that laws that overtly classify on the basis of sex-as segregated restrooms do-are constitutionally unacceptable, in part because they similarly rely on stereotypes about women. In an about-face from Muller, for example, the Supreme Court has recognized that laws that explicitly treat women differently because of "posited sociological or empirical" differences between the sexes are suspect because they often rely on "'old notions" of role typing" and "increasingly outdated misconceptions concerning the role of females in the home rather than in the 'marketplace and world of ideas." 52 Indeed, in Frontiero $v$. Richardson, the Court characterized its own use of separate-spheres language in Bradwell as "an attitude of 'romantic paternalism"" responsible for "statute books . . . laden with gross, stereotyped distinctions between the sexes." 53 The Supreme Court today attempts to root out such "archaic and stereotypic notions" in the law through a heightened standard

(2011). Some examples include ALASKA STAT. ANN. $\$ 18.60 .705$ ("indicating the number of water closets required for females" in various public spaces as part of the state plumbing code); MASS. GEN. LAWS ANN., Ch. 111, $\$ 33$ (requiring "separate water closets for the use of each sex" as part of the state public health code); and WYO. STAT. ANN. \$ 35-15-107 (requiring public assemblies to provide "[s]eparate enclosed toilets for males and females" in order to be licensed). Much of modern bathroom sex-segregation not codified, however, and occurs on a purely permissive or voluntary basis. Cohen, supra, at 81-83, 87, 95-101.

48. Similar sex stereotypes also arise outside of the bathroom context. Professor Reva Siegel, for example, has pointed out a parallel between legislators' reliance on sex-based stereotypes in both the abortion and protective labor legislation contexts: "From the criminalization of abortion to the protective legislation upheld in Muller $v$. Oregon, physiological argument has played an important role in justifying regulation that enforces relations of gender status." Siegel, Reasoning from the Body, supra note 39, at 266.

49. Cohen, supra note 47 , at $82-83$. See, e.g., 43 PA. STAT. ANN. $\S 109$ ("In every establishment where females are employed, toilets, wash-rooms and retiring rooms shall be provided . ..."); TENN. CODE ANN. § 50-1-301 ("All persons employing female employees ... shall provide separate privies or water closets for the female employees.").

50. Kogan, supra note 16 , at 7 .

51. See Georgiana Hickey, Barred from the Barroom: Second Wave Feminists and Public Accommodations in U.S. Cities, 34 FEMINIST STUD. 382, 382 (2008) (describing successful feminist activism leading to the integration of men's clubs, barrooms, and other public accommodations).

52. Craig v. Boren, 429 U.S. 190, 198-99, 208 (1976).

53. 411 U.S. $677,684-85$ (1973) (holding unconstitutional a law that provided lesser benefits for spouses of female air force officers). 
of review for sex-based classifications. ${ }^{54}$ Under such intermediate scrutiny, the Court has invalidated numerous laws, including protective labor legislation, ${ }^{55}$ which relied upon some of the same stereotypes underpinning many early bathroom laws.

\section{B. Sex-Segregated Bathrooms and the ERA Debates}

If the early history of bathrooms suggests they may rely on the kind of sexbased stereotypes unacceptable under intermediate scrutiny, however, the Supreme Court appears to have avoided the question. In one of its most famous sex-discrimination cases, United States v. Virginia, the Supreme Court confronted the question of whether the all-male Virginia Military Institute (VMI) could bar women from admission without violating the Constitution. ${ }^{56}$ Although the case clarified and buttressed a rigorous intermediate scrutiny standard, it did not address bathrooms. Justice Ginsburg, even as she ordered integration of the institution, reassured in a footnote that "[a]dmitting women to VMI would undoubtedly require alterations necessary to afford members of each sex privacy from the other sex in living arrangements," implying that the Court was not concerned with sex-segregated facilities such as bathrooms. ${ }^{57}$

Such treatment, particularly by Justice Ginsburg, might appear surprising given sex-segregated bathrooms' suspect origins. A 1975 opinion piece by thenlitigator Ruth Bader Ginsburg, however, helps account for this quick treatment. Ginsburg wrote the opinion piece in support of the passage of the Equal Rights Amendment (ERA), defending it against common objections or "horribles."58 Confronting charges that the ERA might integrate bathrooms, Ginsburg argued that "regard for individual privacy" would prevent integration. ${ }^{59}$ Ginsburg succinctly captured a common attitude towards bathrooms in a tongue-in-cheek parenthetical: "(Who would bring the testing lawsuit—women who seek access to men's WCs, or men who seek access to women's?)." ${ }^{\prime 60}$ The reassurance seems to be that, even if the ERA might have facilitated suits to integrate bathrooms,

54. Miss. Univ, for Women v. Hogan, 458 U.S. 718, 725 (1982).

55. See, e.g., Craig, 429 U.S. at 210, n.23 (overturning Goesaert v. Cleary, 335 U.S. 464 (1948) and thus holding that laws that forbid most women from working in bars due to "moral and social problems," id. at 466, are unconstitutional).

56. United States v. Virginia, 518 U.S. 515 (1996) [hereinafter VMI].

57. Id. at 550 n. 19 .

58. Ruth Bader Ginsburg, The Fear of the Equal Rights Amendment: Taking Exception, WaSH. Post, Apr. 7, 1975, at A21.

59. "Separate places to disrobe, sleep, perform personal bodily functions are permitted, in some situations required, by regard for individual privacy." Id.

60. Id. 
no one cared enough about sex segregation to sue. ${ }^{61}$ Evidently, Ginsburg, a pioneering feminist litigator, did not envision sex-segregated bathrooms as an important feminist issue, an attitude likely reflected in her $V M I$ opinion almost twenty years later.

Ginsburg was not alone. The history of the ERA debates suggests that other feminists were equally indifferent toward sex-segregated bathrooms; many even voiced support for them. While debates surrounding the proposed ERA may seem an unorthodox place to explore historical feminist attitudes towards sexsegregated bathrooms, the ERA debates capture a rare time when sex-segregated bathrooms were the subject of substantial conversation. Further, as Professor Reva Siegel has argued, the ERA debates played a vital role in "forging modern understandings of discrimination "on account of sex." ${ }^{.62}$ Even though the ERA was not ratified, "the amendment's proposal and defeat played a crucial role in enabling and shaping the modern law of sex discrimination." why feminists appeared unconcerned with sex-segregated bathrooms during the ERA debates, then, helps shed light on why our current sex-discrimination jurisprudence also appears unconcerned with them.

Advocates of the ERA hoped to advance women's equality by amending the Constitution to say that "[e]quality of rights under the law shall not be denied or abridged by the United States or by any State on account of sex." ${ }^{.64}$ The Amendment, first proposed in the 1920 s, became a realistic possibility in the 1970s, when it was passed by both houses of Congress in 1972 and ratified by thirty states by 1973 . Although the ERA gained early momentum through the advocacy of feminist organizations such as the National Organization of Women (NOW), the Amendment's prospects took a sharp turn for the worse after 1973, when a conservative coalition of women began to oppose it vehemently. This STOP-ERA campaign, led by Phyllis Schlafly, cast the ERA as an assault on traditional values and on women's place in the family and society. STOP-ERA, which eventually defeated the Amendment, galvanized opposition among women by arguing the ERA would "strip away safeguards for women and expose them to peril" ${ }^{65}$ while providing few or no benefits.

61. Ginsburg appears to have been right: "An extensive search has revealed no case brought under any state ERA challenging the norm of public single-sex bathrooms." Martha F. Davis, The Equal Rights Amendment: Then and Now, 17 COLUM. J. GENDER \& L. 419, 446 (2008).

62. Reva B. Siegel, Constitutional Culture, Social Movement Conflict and Constitutional Change: The Case of the De Facto ERA, 2005-06 Brennan Center Symposium Lecture, 94 CAL. L. REv. 1323, 1324 (2006) [hereinafter Siegel, Constitutional Culture].

63. Id.

64. JANE J. MANSBRidge, Why WE LOST THE ERA (1986). For more on the history of the ERA ratification process, see DAVID E. KYVIG, EXPLICIT AND AUTHENTIC ACTS: AMENDING THE U.S. CONSTITUTION 1776-2015, 394-425 (2016), and see generally DONALD G. MATHEWS \& SHERRON De HaRT, SeX, Gender and the Politics of the ERA: A State ANd the Nation (1992) and Siegel, Constitutional Culture, supra note 62.

65. KYVIG, supra note 64 , at 410 . 
Although opponents focused on the ERA's potential to eliminate dependent women's entitlements and integrate the military ${ }^{66}$ they also raised the specter of integrated restrooms. In what its proponents labeled the "potty parable" or "potty issue," ${ }^{67}$ Schlafly and her supporters suggested that the ERA, by eliminating sex distinctions in the law, would lead to the integration of restrooms. ${ }^{68}$ In fact, "unisex toilets became one of the four majors themes that activists ... stressed as central to their opposition." ${ }^{\prime 69}$ The fervor of anti-ERA activists' opposition to unisex toilets likely stemmed from their recognition of the link between sexsegregated toilets and the traditional sex roles they hoped to defend. ${ }^{70}$ According to Donald Mathews and Sharon De Hart, anti-ERA advocates saw

[t]he ladies['] room [as] a haven and sanctuary. The men's was a latrine and urinal. To charge that the ERA would integrate toilets was to say that women's washrooms would denigrate into men's rooms. The reality of women's sexual distinctiveness, relative weakness, and sense of vulnerability seemed to be starkly highlighted by the unforgiving brutality of fluorescent feminism. ${ }^{71}$

ERA opponents seem to have understood how sex-segregated facilities reflected traditional models of gender, centering around women's weakness and difference. Proponents, however, did not challenge these assumptions. According to Jane Mansbridge, "every proponent who addressed the issue in [the ERA] debates insisted . . . that the ERA would not require sex-integrated washrooms. ${ }^{" 72}$ Even as they took a starkly egalitarian stance on some highly controversial issues, refusing even to concede that the ERA would not integrate the military, many feminists seemed untroubled that the Act would not integrate restrooms. ${ }^{73}$

Far from seeing sex-segregated toilets as a proper target of the ERA's egalitarian reach, many feminists instead saw opponents' avid focus on them as

66. MANSBRIDGE, supra note 64 , at $84-86$.

67. MATHEWS \& DE HART, supra note 64 , at 165.

68. Id.; MANSBRIDGE, supra note 64, at 112-13.

69. MANSBRIDGE, supra note 64, at 114.

70. See Mary Anne Case, Why Not Abolish Laws of Urinary Segregation?, in TOILET: PUBliC RESTROOMS AND THE POLITICS OF SHARING 211, 225 (Harvey Moltoch \& Laura Noren eds., 2010) ("Many people, among them many women, clearly continue to see [laws of urinary segregation] as a benefit. I am, I must admit, even after careful consideration of the competing arguments, more inclined to see it as a cost. In this, somewhat perversely, I may see eye to eye with Phyllis Schlaflywe each suspect that the achievement of equal rights for women may entail an end to sex segregation in the public toilet.").

71. MATHEWS \& DE HART, supra note 64 , at $165-66$.

72. MANSBRIDGE, supra note 64, at 113.

73. Id. at 84-86 (describing, and characterizing as a potential mistake, feminists' refusal to cede egalitarian principles on issues such as the military in order to make the ERA more politically palatable). 
an opportunity to build political capital. They dismissed the claim that the ERA would integrate toilets as silly, using "[t]his one massive and obvious distortion of the truth ... to label all of the opponents' arguments as lies, irrelevancies, and scare tactics not worthy of serious consideration." 74 This strategy to undermine the opposition was effective. Schlafly quickly backed away from restroom rhetoric because it "backfired in the legislatures," where "the issue served to solidify the conviction of middle-of-the-road legislators that the opposition was irrational." $" 75$

Feminist deployment of sex-segregated bathrooms to undermine the opposition, however, should not be mistaken for ardent approval of them. Feminists did not defend sex-segregated bathrooms as a substantive matter. Like Ginsburg, they merely argued that the ERA would not integrate bathrooms because of "privacy" concerns. ${ }^{76}$ But while this privacy interest was often invoked, as in the VMI footnote, it was little elaborated. ${ }^{77}$ Among the few times that advocates did clarify this privacy interest, their language did not suggest that feminists hoped to defend sex-segregated bathrooms and all their implications. Rather, feminists were willing to use bathrooms as a political tool because they did not see them as subordinating and were thus relatively indifferent towards them.

This ambivalence is perhaps best illustrated by an often-cited pro-ERA article by Thomas Emerson, Barbara Brown, Gail Falk, and Ann Friedman, published in the Yale Law Journal in $1971 .^{78}$ The article, which went so far as to say that the ERA would make sex a "prohibited" classification, nonetheless urged that "the right of privacy would permit the separation of the sexes in public rest rooms." 79 Segregated bathrooms would be permitted by constitutional guarantees of privacy, the authors argued, because privacy is "applicable primarily in situations which involve disrobing, sleeping, or performing personal bodily functions in the presence of the other sex." ${ }^{800}$ Further, because "under

\section{Id. at 114 .}

75. Id. ("Even among those members of the public who opposed the ERA, less than 3 percent gave unisex toilets as either a first, second, or third reason for their opposition."). See also MATHEWS \& DE HART, supra note 64, at 165 (describing how the "potty issue" successfully galvanized antis by triggering gendered and racialized anxieties but also acknowledging that the argument was "easily" dismissed as "silly and groundless" by proponents and legislators).

76. MANSBRIDGE, supra note 64 , at 113.

77. See, e.g., Equal Rights Amendment Not for Women Alone, NORFOLK J. \& GuIDE, Oct. 14, 1972, at Al (quoting Women's Bureau director and ERA advocate Elizabeth Koontz saying that "the Constitution guarantees our right to privacy and, therefore, the concern over not having separate bathrooms for men and women is unfounded").

78. Thomas I. Emerson et al., The Equal Rights Amendment: A Constitutional Basis for Equal Rights for Women, 80 YALE L.J. 871 (1971).

79. Id. at 901 .

80. Id. This Note will discuss at length the tenuousness of the claim that sex-segregated bathrooms advance any of these privacy interests infra Part II.B. 
current mores, disrobing in front of the other sex is usually associated with sexual relationships," privacy interests extended to sex-segregated bathrooms. ${ }^{81}$

This is far from an impassioned defense of sex-segregated bathrooms. Shortly after this brief discussion, in fact, the authors asserted that already"changing" social "mores." might invalidate the just-cited privacy arguments. ${ }^{82}$ Rather than crafting an exhaustive or conclusive privacy defense, the article seemed more focused on discrediting the opposition's concerns as "magnified beyond all proportion" and "dramatic." 83 More importantly, the authors seemed interested in dispatching bathroom objections as quickly as possible, characterizing them as "diversions from the major issues." 84 In contrast to the authors' controversial argument that the ERA could and should substantially impact protective legislation and military segregation, as well as family law and criminal law more broadly, ${ }^{85}$ they dismissed the issue of sex-segregated bathrooms as a mere "diversion."

Underlying the authors' different treatment of sex-segregated bathrooms was their impression that the other sex-based classifications were "subordinating" while "separate toilet facilities in public buildings, . . . carrie[d] no implication of inferiority for either sex." to Ginsburg's in her opinion piece dismissing the bathroom "horrible"- the ERA would not interfere with sex-segregated spaces such as bathrooms because they "protect[] privacy without implying inferiority." ${ }^{87}$ Ultimately, it seems, feminists defended sex-segregated bathrooms against the ERA both because it was politically advantageous and because they did not see them as subordinatingor at least, not subordinating to the class of women that mainstream feminism represented.

Feminists' historical opposition to sex-segregated bathrooms they have seen as subordinating reinforces this assertion. For example, feminists have consistently and effectively protested historically inadequate provision of bathrooms for women in public spaces. ${ }^{88}$ Such "potty parity" activism in the

81. Id.

82. "It should be added that the scope of the right of privacy in this area of equal rights is dependent upon the current mores of the community. Existing attitudes toward relations between the sexes could change over time - are indeed now changing - and in that event the impact of the right of privacy would change too." Id. at 902. By now, the growing number of trans, nonbinary, and gendernonconforming people shows that even the phrase "between the sexes" is dependent on current social mores.

83. Id. at 901,893 .

84. Id. at 893 .

85. See id. at 920-78 (discussing the subordinating effects of protective labor legislation, domestic relations law, criminal law, and military law, which treat women and men differently, and arguing that the ERA would and should rectify these discrepancies).

86. Id. at 902 .

87. Ginsburg, supra note 58 at A21.

88. Kathryn H. Anthony \& Meghan Dufresne, Potty Privileging in Perspective: Gender and Family Issues in Toilet Design, in LADIES AND GENTS: PUBLIC TOILETS AND GENDER 48, 50-53, 56-58 
1980 s resulted in expanded requirements for women's toilets in many states. ${ }^{89}$ When a lack of women's restrooms operated to exclude women in institutions of higher education in the $1960 \mathrm{~s}$, women staged bathroom invasions and protests. ${ }^{90}$ Similarly, when bars attempted to use a lack of women's bathrooms as an excuse to exclude them in the early 1970s, women "liberated' the bathroom[s]" by invading and taking them over. ${ }^{91}$ Feminists' contemporary willingness to challenge other, clearly subordinating instances of bathroom sex segregation suggests their acquiescence to broader bathroom segregation during the ERA debates stemmed at least in part from a failure to understand them as similarly subordinating.

Feminist proponents of the ERA, then, should not be seen as having heartily supported sex-segregated facilities. More likely, they viewed sex segregation of bathrooms as a nonsubordinating and possibly transitory legal distinction and were therefore comfortable defending it for the sake of political expediency. This does not mean that feminists and others have uniformly viewed sex-segregated bathrooms as an important facet of society. To the contrary, it shows that the apparent universality of sex-segregated bathrooms is in large part the result of political strategy. A better understanding of bathrooms' potentially subordinating past—and their present power to subordinate-might dismantle the popular opinion that segregated bathrooms are beneficial for women.

Understanding the origins of sex-segregated bathrooms, and the ERAgenerated debates about them, demonstrates that a lack of controversy should not be mischaracterized as support for bathrooms' continued segregation. There is evidence that bathrooms stem from invidious sex-based stereotypes, and given the terseness and political expediency of feminists' defense of bathrooms, we cannot glean much from their lack of opposition. Ultimately, the ERA debatesan unusually discursive moment in bathrooms' history - tell us very little about how contemporary feminists, scholars, and judges should think about bathrooms. ${ }^{92}$ If sex-segregated bathrooms are to stand up to constitutional

(Olga Gershenson \& Barbara Penner eds., 2009) (identifying the unequal or inadequate provision of women's restrooms as a site of gender discrimination and highlighting activism around these "potty parity" issues).

89. Case, supra note 70 , at 212.

90. Carol P. Christ, Liberation of the Yale Divinity School Library Men's Room, in PULLING OUR OWN STRINGS: FEMINIST HuMOR AND SATIRE 96 (Gloria Kaufman \& Mary Kay Blakely eds., 1980) (describing a takeover or "liberation" of a male-only bathroom by women students at Yale Divinity School in the 1960s); Plaskow, supra note 35, at vii (describing the same incident).

91. Hickey, supra note 51 , at 393.

92. One legal scholar, writing in 1998, came to a similar conclusion after studying the ERA debates: "What would feminists today-radical or liberal-say about the prospect of a law that forbade sexsegregated bathrooms? I really don't know; it doesn't ... get discussed much." Louise M. Antony, Back to Androgeny: What Bathrooms Can Teach Us About Equality, 9 J. CONTEMP. LEGAL ISSUES 1,3 (1998). 
scrutiny, then, their justification must be found outside of their "uncontroversial" history.

\section{THE JURISPRUDENCE OF SEX-SEGREGATED BATHROOMS}

In the absence of clear historical support for sex-segregated bathrooms, it might seem logical to turn to bathroom jurisprudence as an alternative source of legal reasoning in support of their continued existence. While their history is scant, however, case law directly addressing sex-segregated bathrooms is virtually nonexistent. As Justice Ginsburg predicted, no one has brought legal claims challenging them. Even transgender and gender-nonconforming plaintiffs, who routinely face harms arising out of sex-segregated bathrooms, ${ }^{93}$ have not yet challenged their inherent validity in court. Without such a direct challenge, judges, litigators, and other interested parties have not had the opportunity to confront the legal and constitutional implications of sexsegregated bathrooms. As such, sex-segregated bathrooms, and their interaction with the Constitution, have remained distinctly undertheorized in case law.

Despite the absence of case law directly on point, however, judges have indirectly addressed the reasoning behind sex-segregated bathrooms in a number of cases. These cases generally arise in the Title VII context, where sexsegregated facilities have sometimes operated to limit individuals' job opportunities. This occurs, for example, when a woman applies to work as an attendant in a men's restroom ${ }^{94}$ or a male janitor is relegated to a less desirable position so he will not be assigned to clean women's restrooms. ${ }^{95}$ Although these cases do not tackle the validity of sex-segregated bathrooms, they frequently attempt to construct legally cognizable reasons for them. This is because, in order for a bathroom-based employment policy to pass Title VII scrutiny, an employer must often show that being the "right" sex to work in the bathroom is a Bona Fide Occupational Qualification (BFOQ). ${ }^{96}$ In other words, an employer must demonstrate that an employee is categorically unqualified for a job that requires

93. For instance, sex-segregated restrooms are sites of subordination and violence for many transgender women and other gender nonconforming people, in part because of their reinforcement of gender stereotypes and sexual difference. In one survey, $70 \%$ of transgender and gender nonconforming people reported "being denied access, verbally harassed, or physically assaulted in public restrooms." Jody L. Herman, Gendered Restrooms and Minority Stress: The Public Regulation of Gender and Its Impact on Transgender People's Lives, 19 J. OF PUB. MGMT. \& SOC. POL'Y 35, 35 (2013).

94. Norwood v. Dale Maint. Sys., Inc., 590 F. Supp. 1410 (N.D. Ill. 1984).

95. Hernandez v. Univ. of St. Thomas, 793 F. Supp. 214, 217 (D. Minn. 1992).

96. Title VII prohibits a covered employer from "limit[ing], segregat[ing], or classify[ing]" employees based on sex. 42 U.S.C. $\$ 2000 \mathrm{e}-2(\mathrm{a})(2)$ (2012). Title VII contains an exception, however, for "bona fide occupational qualification[s]," commonly called BFOQs. The statute provides that a BFOQ exists if sex-based hiring, referring, or classifying of workers is "reasonably necessary to the normal operation of that particular business or enterprise." 42 U.S.C. $§ 2000 \mathrm{e}-2$ (e) (2012). 
them to enter or observe an opposite-sex restroom. As judges evaluate whether an employee's presence in the "wrong" restroom is reason enough to disqualify them from employment, they necessarily confront the reasons for having sexsegregated bathrooms in the first place.

Another more recent source of judicial reasoning about sex-segregated bathrooms emerges from contemporary transgender bathroom-access litigation. Those who argue in court that transgender individuals must be excluded from the "wrong" bathroom necessarily argue that so-called "biological" sex-based segregation serves important interests. Judges must evaluate these asserted interests and the degree to which strictly sex-segregated bathrooms serve them. Transgender bathroom litigation, like Title VII case law, presents an unusual situation in which judges need to construct some legal reasoning behind sexsegregated bathrooms.

Although judges' reasoning about bathrooms is diverse, a survey of Title VII case law and transgender bathroom litigation reveals a common pattern. Judges repeatedly return to two primary interests to justify sex segregation in bathrooms: privacy and safety. Judges also bring up a subsidiary interest of accommodating biological differences. These interests align with common lay defenses of sexsegregated bathrooms. ${ }^{97}$ Unfortunately, much like feminists during the ERA debates, judges often invoke these interests without explaining them in any depth. Unlike the reasoning of political actors, however, judicial reasoningparticularly in the realm of sex-based distinctions in law-requires more careful inspection. This Part will explore the contours of the biological, privacy, and safety interests that judges assert as justifications for sex-segregated bathrooms. This Part will seek to refine and concretize these interests before subjecting them to more rigorous scrutiny in Part III.

\section{A. The Interest in Accommodating Biological Differences}

Judges have often, particularly in the context of transgender litigation, grounded discussions of sex-segregated bathrooms in some notion of "biological" or "physiological" differences. A typical version of this reasoning appears in dicta from a sex-based equal protection case, Faulkner v. Jones. ${ }^{98} \mathrm{In}$ deciding whether a school's all-male admissions policy violated the Constitution, a judge explained that "'separate-but-equal' facilities" are acceptable only if "justified by acknowledged differences." "99 The judge then invoked bathrooms as

97. In her essay on sex-segregated bathrooms, Louise Antony noted that when she asks people why bathrooms are sex-segregated, almost all "give[] one of three answers: they say either a) we do it because the anatomical differences between men and women are relevant to the purposes of bathrooms; or b) it's necessary to secure the safety of women in a sexist world; or c) it's necessary in order to provide people with 'privacy."' Antony, supra note 92, at 4.

98. 10 F.3d 226 (4th Cir. 1993)

99. Id. at 232 (emphasis omitted). 
an example: "[t]he point is illustrated by society's undisputed approval of separate public rest rooms for men and women .... The need for privacy justifies separation and the differences between the genders demand a facility for each gender that is different." 100 The district court deciding G.G. v. Gloucester County cited this language to support a restriction of transgender students' restroom access: "[r]estrooms . . . are designed differently because of the biological differences between the sexes. ... Male restrooms, for instance, contain urinals, while female restrooms do not. Men tend to prefer urinals because of the convenience." 101 These arguments are used to justify not only the exclusion of transgender people from sex-segregated restrooms, but also the existence of sexsegregated spaces in the first place. The exclusion of transgender, intersex, and nonbinary people is baked into the very premise of "sexual difference."

In a further appeal to such interests, the United States District Court for the Middle District of North Carolina recently offered a colloquy on the importance of "physiological differences" in Carcaño v. McCrory. ${ }^{102}$ The case concerned a challenge to a North Carolina law requiring that multiple-occupancy bathrooms be designated for and used by persons based on their biological sex. ${ }^{103}$ The court catalogued various examples of physiology as a source of justification for sex segregation and concluded that "physiological differences between men and women give rise to the privacy interests that justify segregating bathrooms, showers, and other similar facilities on the basis of sex." 104 These interests alone were significant enough to support a holding that the plaintiffs were unlikely to succeed on the merits of their equal-protection claim.

Notably, the interest the judges invoke in these cases is not an interest in biological difference itself but rather an interest in accommodating that difference. Bathrooms tailored to each sex help accommodate biologically driven "demands," making things more "convenien[t]" for everyone. It is also important to note that the judges do not assert this interest on its own to justify segregation. In Faulkner, the judge implied that an interest in accommodating "the differences between the genders" works in tandem with "privacy" to make "separate but equal" bathrooms constitutionally permissible. ${ }^{105}$ The G.G. and Carcaño opinions took similar approaches. Immediately after discussing biological differences that require different facilities, the G.G. court continued that "society demands that male and female restrooms be separate because of privacy

100. Id.

101. G.G. ex rel. Grimm v. Gloucester Cty. Sch. Bd., 132 F. Supp. 3d 736, 750 (E.D. Va. 2015), rev'd in part, vacated in part, 822 F.3d 709 (4th Cir. 2016) (citations omitted).

102. 203 F. Supp. 3d 615, 643 (M.D.N.C. 2016).

103. The court defined biological sex as the sex listed on individuals' birth certificates. $I d$. at 621 .

104. Id. at 645 .

105. Faulkner v. Jones, 10 F.3d at 232. 
concerns." 106 Further, sex segregation is necessary to advance "universally accepted protections of privacy and safety that are based on the anatomical differences between the sexes."107 The Carcaño court held that "physiological differences," primarily people's "genitals," give rise to special privacy interests. While differing biological needs may create an interest in providing differing facilities, it is privacy and safety interests that mean these sex-specific accommodations must be provided in the form of segregated restrooms, rather than one common facility fully equipped to serve "both" sexes.

An interest in accommodating biological difference, then, is less an independent interest judges use to justify sex segregation and more an interest linked to issues of privacy and safety. Nonetheless, it is important to note at the outset that some judges overtly attach importance to notions of biological difference in the bathroom context. Other judges-who do not overtly mention biological differences-implicitly rely on these same differences. As the rest of this Part will discuss, assumptions about biological difference underpin most assertions of privacy or safety interests.

\section{B. The Interest in Protecting Privacy}

The interest that judges most commonly assert as a justification for sexsegregated bathrooms is privacy. The primary Supreme Court decision touching on the question of sex-segregated bathrooms, as discussed in Part I, uses privacy as its justification. Again, in a footnote to $V M I$, Justice Ginsburg held that even though Virginia must integrate its military institute, "[a]dmitting women to VMI would undoubtedly require alterations necessary to afford members of each sex privacy from the other sex in living arrangements. ..."108 Although the footnote does not overtly mention bathrooms, it is often cited in lawsuits over bathroom use, and the privacy interest it invokes is a common feature of contemporary transgender bathroom litigation. ${ }^{109}$ The privacy interest, however, far predates

106. G.G., 132 F. Supp. 3d at 750.

107. G.G. ex rel. Grimm v. Gloucester Cty. Sch. Bd., 822 F.3d 709, 730 (4th Cir.) (Niemeyer, J., concurring in part and dissenting in part), cert. granted in part, 137 S. Ct. 369 (2016), vacated and remanded, No. 16-273, 2017 WL 855755 (U.S. Mar. 6, 2017). In its decision to enjoin the Obama Administration's Title IX guidance, a Texas district court also subsumed biology under privacy, reasoning that "separation from members of the opposite sex, those whose bodies possessed a different anatomical structure, was needed to ensure personal privacy" in the bathroom. Texas v. United States, 201 F. Supp. 3d 810, 833 (N.D. Tex. 2016), order clarified, No. 7:16-CV-00054-O, 2016 WL 7852331 (N.D. Tex. Oct. 18, 2016).

108. United States v. Virginia, 518 U.S. 515,550 n.19 (1996).

109. Privacy rights were a ubiquitous assertion by plaintiffs challenging the Obama Administration's Title IX guidance, for example. For just a few examples, see Bd. of Educ. of the Highland Local Sch. Dist. v. U.S. Dep't of Educ., 208 F. Supp. 3d 850 (S.D. Ohio Sept. 26, 2016), appeal docketed, No. 16-4117 (6th Cir. Sept. 29, 2016); Students \& Parents for Privacy v. U.S. Dep't of Educ., No. 1:16-cv-4945 (N.D. Ill. June 15, 2016); Privacy Matters v. U.S. Dep't of Educ., No. 16-cv-3015 (D. Minn. Oct. 27, 2016). 
the 1993 VMI opinion, featuring in bathroom-related Title VII litigation dating back to the 1970 s.

If the privacy justification is ubiquitous, however, it is also vague. Much like in the $V M I$ footnote, judicial mentions of privacy as a justification for sexsegregated facilities are often limited to one or two sentences and are largely unelaborated. ${ }^{110}$ Despite judges' apparent reluctance to expand on the privacy interest at stake in sex-segregated bathrooms, it is nonetheless possible to identify some aspects of this interest by broadly examining Title VII and transgender bathroom case law.

A large component of the privacy interest in the sex segregation of bathrooms appears to relate to nudity and a right to protect one's naked body from unwanted exposure. This interest first appears in a 1963 case called York $v$. Story, which held that there is no "more basic subject of privacy than the naked body. The desire to shield one's unclothed figure[] from view of strangers, and particularly strangers of the opposite sex, is impelled by elementary self-respect and personal dignity." $" 111$ Courts often, albeit only indirectly, assert this interest as a reason people cannot go into the "wrong" bathroom.

In Norwood v. Dale Maintenance Systems, for example, a court held that being male was a BFOQ for attendants of men's bathrooms because "men would not be able to urinate if a woman were present in the men's washroom."112 The court appears to suggest that, if a woman were present, a man could not use the bathroom because of an intolerable risk of bodily exposure. The district court employs the same logic euphemistically in the G.G. case. It found that a transgender boy's presence in a men's restroom would be unacceptable in part "because people sometimes turn while closing their pants." ${ }^{\text {"13 }}$ With a meticulous sense of propriety that appears to forbid even directly describing the relevant risk, the court implies that transgender boys cannot share a bathroom with cisgender boys due to an intolerable risk of genital exposure. More directly, the Carcaño court asserted an uncontested privacy "interest in ... ensuring that " 12 -

110. Faulkner v. Jones's assertion that "society's undisputed approval of separate public rest rooms for men and women [is] based on privacy concerns" provides a typical example. $10 \mathrm{~F} .3 \mathrm{~d} 226,232$ (4th Cir. 1993). See also Texas v. United States, 201 F. Supp. 3d at 833 (urging that Title IX regulations allowing for separate bathrooms were based on the recognition that "separation from members of the opposite sex, those whose bodies possessed a different anatomical structure, was needed to ensure personal privacy" but offering no further explanation).

111. York v. Story, 324 F.2d 450, 455 (9th Cir. 1963), cert. denied, 376 U.S. 939 (1964). While courts frequently cite this case in relation to bathrooms, they often fail to explain the fairly egregious facts out of which this language emerged. York $v$. Story concerned a group of police officers coercing a woman to undress and pose for sexualized nude pictures when she came in to report an assault. The police officers then distributed the photos without her permission. Analogizing coercive photography and distribution of images of a woman's naked body to the accidental and temporary exposure possible in a bathroom is misleading. For an example of such a misleading quotation, see G.G., 132 F. Supp. 3d at 751 (citing York v. Story).

112. Norwood v. Dale Maint. Sys., Inc., 590 F. Supp. 1410, 1417 (N.D. Ill. 1984).

113. G.G., 132 F. Supp. 3d at 751 (E.D. Va. 2015), rev'd in part, vacated in part, 822 F.3d 709 (4th Cir. 2016). 
year-old girls who are not familiar with male anatomy' are not exposed to male genitalia by "somebody older""114 to justify excluding all transgender people from the "wrong" bathrooms. Evidently, sex-segregated bathrooms protect privacy interests by shielding users from unwanted exposures of their bodies and from unwanted exposure to the bodies of others.

There is also another, narrower aspect of the asserted privacy interest in bathroom segregation. As one court put it, sex-segregated public restrooms "respect[]" "the sanctity of the right of privacy in the performance of excretory functions." ${ }^{115}$ Distinct from an interest in preventing exposure of the body itself, this privacy interest instead seeks to prevent exposure of what the body does in the bathroom. This component of privacy seems to cover a whole range of sights and sounds that may occur when someone is in the bathroom-protecting from disclosure the smells and sounds that accompany excretion, ${ }^{116}$ the sight of menstrual blood ${ }^{117}$ or sanitary products, ${ }^{118}$ or even the fact that one has used the bathroom at all. ${ }^{119}$ In addition to the risk of bodily exposure, risk of these more subtle kinds of exposure may explain why a judge insisted that if a woman janitor were present in a bathhouse, men would be "unable to use the toilet facilities in that bathhouse without suffering violation of their privacy rights." 120 Understanding the exact nature of this second, more specific privacy right,

114. Carcaño v. McCrory, 203 F. Supp. 3d 615, 644 (M.D.N.C. 2016) (citations omitted).

115. Local 567 Am. Fed'n of State, Cty., \& Mun. Employees v. Michigan Council 25, Am. Fed'n of State, Cty., \& Mun. Employees, 635 F. Supp. 1010, 1012 (E.D. Mich. 1986) (citing A. Larson, Employment Disc.-Sex § 1430, 4-8 (3d ed. 1980)).

116. Although my research turned up no instances of judges directly discussing this aspect of the "sanctity" of bathroom privacy, anxieties about sights and smells are undoubtedly part of this interest. As Ruth Barcan has suggested, "[i]f we were rid of the shames of smell and sound, perhaps men and women might even consent to share the same physical space" of the bathroom. Ruth Barcan, Dirty Spaces: Separation, Concealment, and Shame in the Public Toilet, in TOILET: PUBLIC RESTROOMS AND THE POLITICS OF SHARING 25, 38 (Harvey Moltoch \& Laura Noren eds., 2010).

117. One judge, for example, held that female sex is a BFOQ for a women's prison guard because "[s] ome inmates may wish to use the toilet upon arising ... one may find her night clothes and bedding visibly soiled from an unexpected menstrual flow and wish to clean up." Forts v. Ward, $471 \mathrm{~F}$. Supp. 1095, 1101 (S.D.N.Y. 1978), vacated in part, 621 F.2d 1210 (2d Cir. 1980). The judge continued that, "[u]nder these circumstances, I deem it inappropriate for a male guard to be making the first count of the morning with the inmates just awakened and their doors locked open." Id.

118. See, e.g., Everson v. Michigan Department of Corrections, 391 F.3d 737, 758 (2004) (holding that female sex was a BFOQ for a women's prison in part because "the officers ... supervise 'the most intimate aspects of an inmate's life,"” such as when they "use the restroom" or "request sanitary items" (citations omitted)).

119. This is implied, for example, by an Illinois judge's language in Norwood v. Dale Maintenance Systems, which held that male sex was a BFOQ for cleaning a men's restroom. Even though plaintiffs suggested that female janitors could simply leave the restroom if men needed to use it, the court rejected this because "tenants would be faced with a greater probability of embarrassing or stressful confrontations with cleaning attendants of the opposite sex in their washroom." $590 \mathrm{~F}$. Supp. 1410 , 1423 (N.D. Ill. 1984). There is no reason that this situation would be "embarrassing or stressful" unless an attendant merely knowing that you are using the restroom violates a privacy interest.

120. Brooks v. ACF Indus., Inc., 537 F. Supp. 1122, 1132 (S.D. W. Va. 1982) (holding that male sex was a BFOQ for being a janitor in a men's locker room and toilet facility). 
however, is still more difficult given judges' even greater reluctance to directly discuss it in their opinions. ${ }^{121}$

Despite some fuzziness about the reach of the privacy interest in protecting the naked body and its functions from disclosure, and innocent eyes from exposure, one thing is clear: in the context of bathroom segregation, these privacy interests are imagined to exist primarily against the "opposite sex." York $v$. Story stated this concept explicitly when it established a privacy interest in "shield[ing] one's unclothed figure[] from view of strangers, and particularly strangers of the opposite sex."

The point is further illustrated by Norwood v. Dale Maintenance Systems, in which the court suggested that the only acceptable solution to the privacy concerns posed by opposite-sex bathroom attendants was to forbid women from working in men's rooms and vice versa. ${ }^{123}$ Norwood rejected the alternatives the plaintiff offered, such as having the attendant knock before entering or having her leave if a man entered, reasoning that "privacy would be invaded to a degree under any opposite sex system." 124 In reaching the conclusion that no genderneutral solution was required, the court relied heavily on expert testimony that "the current same sex policy imposes no stress on the users of the washrooms, whereas . . . the invasion of privacy that would be created by an opposite procedure would be extreme." 125 In other words', a man using the bathroom in the presence of a male attendant creates little to "no" privacy issue, whereas a man using the bathroom in the presence of a female attendant creates an "extreme" privacy issue.

Judges have repeatedly emphasized that these privacy interests operate relative to the "opposite sex." 126 The current state of public restrooms confirms this: if people had a privacy interest in protecting exposure of their bodies and bodily functions from all people, urinals would present an unacceptable violation of privacy, and the presence of a bathroom attendant of any sex would constitute an "extreme" invasion of privacy. Further, if courts were worried about unwanted

121. This unwillingness to delve too deeply into this issue is perhaps best captured by a Michigan judge: "[S]ince the essence of the matter here under consideration is personal privacy, there are no imperatives, no 'shoulds' or 'shouldn'ts.' That is the essence of privacy, that there is no norm. It is private." Local 567 Am. Fed'n of State, Cty., \& Mun. Employees v. Michigan Council 25, Am. Fed'n of State, Cty., \& Mun. Employees, 635 F. Supp. 1010, 1014 n.7 (E.D. Mich. 1986). As Judith Plaskow has observed, "[ $[$ ] he topics of gender, sexuality, and the body have been all the academic fashion for four decades, but the issue of toilets seems to be surrounded by the same embarrassment and taboos that generate toilet jokes in the wider culture." Plaskow, supra note 35, at viii.

122. York v. Story, 324 F.2d 450, 455 (9th Cir. 1963) (emphasis added), cert. denied, 376 U.S. 939 (1964).

123. Norwood, 590 F. Supp. at 1422 .

124. Id.

125. Id. at 1417 (emphasis added) (citing Plaintiffs' Reply 89).

126. Texas v. United States, No. 7:16-CV-00054-O, 2016 WL 4426495, at *14 (N.D. Tex. Aug. 21, 2016) (noting that students "have a privacy right to avoid exhibiting their 'nude or partially nude body, genitalia, and other private parts' before members of the opposite sex") (emphasis added). 
exposure of naked bodies to innocent eyes as a general matter, the Carcaño court would extend its worry about "12-year-old girls" to 12-year-old boys exposed to "mature" "male genitalia" at these same urinals. ${ }^{127}$ Sex-segregated bathrooms, in fact, do little to serve sex-neutral privacy interests because they do not necessarily protect people from unwanted bodily exposure to members of their same sex. They do, however, appear to serve sex-specific privacy interests. Sex segregation, by keeping men and women in different rooms, certainly makes it less likely that a man or woman will see or hear someone of the opposite sex while in the bathroom.

The privacy interest that judges assert sex-segregated bathrooms serve, however, can be clarified further-by examining the injury judges imagine integration might produce. A California court phrased it most succinctly in a 1976 case, In re Long, which condemned the use of female observers in the toilet facilities of a prison for young men. The court not only held that the practice violated sex-specific privacy interests, but also described the specific injury that such privacy interests seek to prevent: "injured self-esteem, humiliation and embarrassment arising out of enforced nudity and conduct of bodily functions within the perceptive range of members of the opposite sex." 128 The "privacy interests" at stake in sex-segregated bathrooms, then, are not only in preventing unwanted exposure of one's body or bodily functions to members of the opposite sex (or unwanted exposure to such "opposite" bodies), but also in preventing the embarrassment and shame that would result from such exposure. ${ }^{129}$

In re Long is not the only decision to draw this link between sex-segregated restrooms and the prevention of embarrassment or shame. The Norwood court rejected the possibility of female bathroom attendants in part because it might lead to "embarrassing or stressful confrontations." 130 Female attendants knocking before entering, the court noted, would not alleviate such stress because "the knock may not be heard due to distance from the door or the noise caused by running water." 131 Discussing the privacy interests at stake in sex-segregated prison facilities, another judge held that male presence at night in a women's facility creates "the risk of at least embarrassment or shame or humiliation."132 Litigants seeking to prevent transgender access to bathrooms often invoke the

127. Carcaño v. McCrory, 203 F. Supp. 3d 615, 644 (M.D.N.C. 2016).

128. In re Long, 127 Cal. Rptr. 732, 735 (Ct. App. 1976).

129. For an example of such reasoning in the hospital BFOQ context, see Jones v. Hinds Gen. Hosp., 666 F. Supp. 933, 936 (S.D. Miss. 1987) (upholding a hospital's discriminatory layoff policy on the grounds that the hospital needed to ensure that there were enough male orderlies on staff to catheterize patients, a task female nurses could not perform under hospital policy in order to avoid embarrassment to male patients).

130. Norwood v. Dale Maint. Sys., Inc., 590 F. Supp. 1410, 1423 (N.D. Ill. 1984).

131. Id.

132. Forts v. Ward, 471 F. Supp. 1095, 1101 (S.D.N.Y. 1978), vacated in part, 621 F.2d 1210 (2d Cir. 1980). 
embarrassment, humiliation, and shame caused by sharing bathrooms with the "opposite" sex, ${ }^{133}$ and this language has been picked up by some courts as well. ${ }^{134}$ As the Carcaño court fastidiously noted, "It is also possible that sexsegregated facilities protect against embarrassment from engaging in intimate bodily functions in the immediate vicinity of the opposite sex, regardless of whether one's body is subject to view."135

The social and cultural poignancy of this shame-related, sex-specific privacy interest is perhaps best articulated by Judge Posner, in his dissent in Johnson $v$. Phelan. ${ }^{136}$ In this case, a male prisoner argued that his constitutional privacy rights were violated when female guards were "assigned to monitor male prisoners' movements and c[ould] see men naked in their cells, the shower, and the toilet." ${ }^{137}$ Although the majority rejected the plaintiff's privacy argument, partially because courts have held prisoners to have fewer privacy rights than nonincarcerated persons, ${ }^{138}$ Judge Posner wrote an impassioned dissent defending the fundamental importance of opposite-sex privacy rights. In his dissent, Judge Posner urged that requiring prisoners to be monitored by oppositesex guards treats them "no better than animals" and akin to dogs "in a kennel."139 Because of a "nudity taboo" that "is particularly strong" against "the opposite sex," cross-sex guarding inevitably produces embarrassment, shame, and anxiety so extreme that it amounts to "the infliction of [a] cruel and unusual psychological punishment[]."140

In Judge Posner's view, then, a privacy interest against the opposite sex rises to the level of a basic right and an essential component of our humanity. The interest is so strong, in fact, that it rightfully overcomes the sex-based equality

133. See, e.g., Brief of The Family Foundation of Virginia, et al. as Amicus Curiae in Support of Defendant-Appellee at 17, G.G. ex rel. Grimm v. Gloucester Cty. Sch. Bd., 132 F. Supp. 3d 736 (E.D. Va. 2015) (No. 15-2056); Complaint at 932 , Women's Liberation Front v. U.S. Department of Justice et al., No. 1:16-cv-00915 (D.N.M. August 11, 2016).

134. G.G., 132 F. Supp. 3d at 752, rev'd in part, vacated in part, 822 F.3d 709 (4th Cir. 2016).

135. Carcaño v. McCrory, 203 F. Supp. 3d 615, 623 (M.D.N.C. 2016).

136. 69 F.3d 144 (7th Cir. 1995).

137. Id. at 145 .

138. Id. at 146 ("Hudson v. Palmer, 468 U.S. 517, 526-30, 104 S.Ct. 3194, 3200-02, 82 L.Ed.2d 393 (1984), observes that privacy is the thing most surely extinguished by a judgment committing someone to prison. Guards take control of where and how prisoners live; they do not retain any right of seclusion or secrecy against their captors, who are entitled to watch and regulate every detail of daily life.").

139. Id. at 151-52 (Posner, J., dissenting).

140. Id. at 152,154 . 
values of Title VII. ${ }^{141}$ Judge Posner criticizes "radical feminists"142 who ignore such opposite-sex privacy rights, urging that they make the error of pursuing "sexual equality ... with no regard to competing interests, and with an eye blind to reality." 143 While this impassioned dissent is in reaction to state-enforced opposite-sex observation far more extensive than what occurs in any public restroom, its appeal to "reality" and the importance of cultural norms differs only in degree from judges' reasoning in cases involving attendants in public bathrooms. Whether it is a knock on the bathroom door or direct observation, the psychological harm-embarrassment, anxiety, or shame-produced by the threat of exposure of one's body or bodily functions to members of the opposite sex is a "reality" that deeply concerns judges.

Taken together, courts' somewhat vague invocations of "privacy" take a more concrete form: an interest in avoiding the embarrassment, stress, or shame caused by unwanted exposure of one's body or bodily functions to members of the opposite sex (or unwanted exposure to such "opposite" bodies and functions). While judges and others clearly understand this interest to be fundamentally important, identifying the interest in specific terms is essential to understanding whether it is ultimately "important" enough to withstand intermediate scrutiny. Further, it helps illuminate whether bathrooms actually serve this interest. More importantly, as Part III will discuss, understanding the specific nature of this interest helps reveal how broad, "reality"-based, and apparently innocuous invocations of privacy in the bathroom context actually import and preserve invidious sex-based stereotypes about biology, modesty, and sexual difference in the law.

\section{The Interest in Protecting Women's Safety}

Conservative advocates frequently invoke fears about women's safety as a justification for "keeping men out of the women's bathroom" in contemporary transgender bathroom-access debates. ${ }^{144}$ Such language is not new; opponents of the ERA also invoked the image of "rapists" in the bathroom in an attempt to

141. "I have no patience with the suggestion that Title VII of the Civil Right Act of 1964 forbids a prison or jail to impede, however slightly, the career opportunities of female guards by shielding naked male prisoners from their eyes." Id. at 153.

142. "There are radical feminists who regard 'sex' as a social construction and the very concept of 'the opposite sex,' implying as it does the dichotomization of the 'sexes' (the 'genders,' as we are being taught to say), as a sign of patriarchy." Id. at 152.

143. Id. at 155 .

144. John Hawkins, When Did It Become Controversial to Keep Men Out of the Women's Bathoom?, TOWNHALL, Apr. 5, 2016, https://townhall.com/columnists/johnhawkins/2016/04/05/when-did-itbecome-controversial-to-keep-men-out-of-the-womens-bathroom-n2143586 [https://perma.cc /VQ3Y-2S23]; see also Elizabeth Edens, Commentary: Keep Men Out of Women's Restrooms, CHI. TRIB., Apr. 7, 2016, http://www.chicagotribune.com/news/opinion/commentary/ct-bathroomstransgender-north-carolina-women-men-perspec-0408-20160407-story.html [https://perma.cc /RE47-7DMW]. 
undercut the Amendment. ${ }^{145}$ Such concerns have also featured in judicial reasoning. In addition to relying on biological difference and privacy, judges have often relied on an interest in protecting women's safety as a reason to keep spaces such as restrooms strictly sex-segregated. A number of Title VII cases addressing similarly sex-segregated spaces help illuminate the details of this safety interest.

Invocations of women's safety as a justification for sex-segregated bathrooms feature prominently in briefs and complaints in the transgender litigation context. In a suit challenging the Obama Administration's transinclusive Title IX guidance, for example, a group of self-described "radical feminists" asserted that allowing transgender women into women's bathrooms would undermine the "safety offered by restrooms" and would lead to an "increased risk of sexual assault." 146 The Gloucester County School Board invoked similar safety concerns as a reason for excluding students from the "wrong" restroom, ${ }^{147}$ and North Carolina Governor McCrory asserted the "safety of women and children" as a primary motivation for the state's Bathroom Bill in Carcaño. ${ }^{148}$ When transgender woman Krystal Etsitty's employer fired her because she used women's restrooms along her route, the company defended itself from Title VII liability by suggesting that "[w]omen have legitimate concerns about privacy and safety underlying their desire not to share restrooms ... with men."149.

While safety concerns frequently feature in litigants' arguments, however, judges have dedicated even less time to explicating this safety justification for sex-segregated bathrooms than they have to the privacy justification. The Ninth Circuit's denial of a transgender woman's Title VII claim after she was fired for using the women's restroom is one example. Even though the plaintiff was able to establish a prima facie case of sex discrimination, the court held that it was overcome by the School Board's "evidence that it [had] banned [the plaintiff] from using the women's restroom for safety reasons." 150 The court offered no

145. See, e.g., MANSBRIDGE, supra note 64 , at 113 ("The unisex toilet issue fed the fervor of the antiERA forces by giving them something absolutely outrageous to focus on. It could conjure up visions of rape by predatory males."); Neil J. Young, How the Bathroom Wars Shaped America, POLITICO, May 18, 2016, http://www.politico.com/magazine/story/2016/05/2016-bathroom-bills-politicsnorth-carolina-lgbt-transgender-history-restrooms-era-civil-rights-213902 [https://perma.cc/SV9VVRZJ].

146. Complaint at $\uparrow$ 30, 32, Women's Liberation Front v. U.S. Department of Justice et al., No. 1:16cv-00915 (D.N.M. August 11, 2016).

147. G.G. ex rel. Grimm v. Gloucester Cty. Sch. Bd., 822 F.3d 709, 723 n.11 (4th Cir. 2016) (discussing, and dismissing, "the Board's invocation of amorphous safety concerns" as a reason for traditional sex segregation in bathrooms).

148. Carcaño v. McCrory, 203 F. Supp. 3d 615, 645 (M.D.N.C. 2016).

149. Brief of Appellees Utah Transit Authority \& Betty Shirley at 32, Etsitty v. Utah Transit Auth., 502 F.3d 1215, 1219 (10th Cir. 2007) (No. 05-4193), 2005 WL 3749267.

150. Kastl v. Maricopa Cty. Cmty. Coll. Dist., 325 F. App'x 492, 494 (9th Cir. 2009). 
further elaboration. The district court in G.G. was similarly taciturn. While it hinted that sex-segregated bathrooms were necessary to the School Board's task of "providing safe and appropriate facilities for ... students," it did not explain this assertion. ${ }^{151}$ Likewise, the Carcaño court merely noted that the state-asserted safety interest for the Bathroom Bill was legitimate without further elaboration. ${ }^{152}$

Nonetheless, Judge Niemeyer's dissent to the Fourth Circuit's decision in G.G. once again offers elaboration where other judges have been less explicit. Niemeyer protested that allowing transgender students to use a bathroom that aligns with their gender identity "overrules . . . the very demands inherent in human nature for privacy and safety, which the separation of such facilities is designed to protect." "153 While the dissent conflates interests in accommodating biological difference, preserving privacy, and protecting safety, it hints at what the "safety" risk specifically entails. The dissent describes "safety concerns that could arise from sexual responses prompted by students' exposure to the private body parts of students of the other biological sex." 154 The judge appears to be voicing a concern-albeit euphemistically-about sexual vulnerability and sexual assault. Perhaps, then, sex-segregated bathrooms serve the specific safety interest of protecting people from sexual assault.

Although there is little other case law elaborating the safety interest in the particular context of bathroom segregation, judges have more fully addressed a similar safety interest in other forms of sex segregation. In Title VII suits addressing sex-segregated prisons and hospital wards, for example, judges have held sex to be a BFOQ because of concerns about safety, and more specifically concerns about sexual assault. Understanding the reasoning in these opinions may help illuminate judges' implicit beliefs about the safety interests underpinning sex-segregated bathrooms - or at least highlight which safety arguments about bathrooms will find most precedential support in courtrooms.

Perhaps the most significant case addressing this safety interest is Dothard v. Rawlinson, in which the Supreme Court upheld a regulation barring women from applying to be guards in a male prison. The Court hinged its analysis on women's vulnerability to sexual assault: "The likelihood that inmates would assault a woman because she was a woman would pose a real threat not only to the victim of the assault but also to the basic control of the penitentiary and protection of its inmates and the other security personnel." ${ }^{.155}$ In other words, the

151. G.G. ex rel. Grimm v. Gloucester Cty. Sch. Bd., 132 F. Supp. 3d 736, 751 (E.D. Va. 2015), rev'd in part, vacated in part, 822 F.3d 709 (4th Cir. 2016).

152. McCrory, 203 F. Supp. 3d at 622.

153. G.G. ex rel. Grimm v. Gloucester Cty. Sch. Bd., 822 F.3d 709, 731 (4th Cir. 2016) (Niemeyer, J., concurring in part and dissenting in part), cert. granted in part, 137 S. Ct. 369 (2016), vacated and remanded, No. 16-273, 2017 WL 855755 (U.S. Mar. 6, 2017).

154. Id. at 735 .

155. 433 U.S. 321,336 (1977). 
presence of a woman in the sex-segregated space of the male prison would produce inevitable safety concerns for both sexes. Women would be faced with the danger of becoming victims of sexual assault, and men would be faced with the danger of disorder in the prison. The Court also seemed to suggest a "risk" of men becoming sexual assailants. ${ }^{156}$

This concern for the man who might commit sexual assault is detailed more explicitly in Long $v$. State Personnel Board. The California court in Long held that a woman could be barred from applying to be a chaplain in a male youth prison. ${ }^{157} \mathrm{~A}$ woman might not be suited to serve as a chaplain, the court explained, because of the "danger from sexual attack." who are generally raped, not men," this same danger did not exist for male chaplains. ${ }^{159}$ While the court emphasized the danger of sexual assault for women, however, its decision did not turn on this danger. Rather, the court was more concerned with the "disastrous" "effect upon the [male] ward who succumbs to temptation and commits the sexual offense."160 Women's presence would not only put them at risk of becoming victims but would also inevitably put men at risk of becoming victims of their own unbridled sexuality. In Backus v. Baptist Medical Center, a judge followed similar reasoning to justify barring men from working in the obstetrics ward of a hospital: "a male nurse would necessitate the presence of a female nurse to protect the hospital from charges of molestation." 161 Here, it was a hospital, in addition to women and men, that needed to be protected from men's sexuality.

In all of these cases, judges offer arguments that allowing the "wrong" sex into strictly sex-segregated spaces would threaten the safety of both men and women by increasing the risk of sexual assault. In doing so, the judges hold that sex-segregated spaces serve two specific safety interests. First, sex-segregated spaces protect women from sexual assault. Second, they protect at least some men-and employers who hire men-from unbridled male heterosexuality, which inevitably leads to sexual assault. Although these judges did not assert these interests to justify sex-segregated bathrooms specifically, they offer helpful elaborations of Judge Niemeyer's vague "safety concerns that could arise from

156. The Court's claim that the presence of a woman would threaten the "basic control" of the prison because it is so "likel[y]" she would be assaulted suggests that the inmates' proclivity for sexual violence is so extreme that only the absence of heterosexual temptation "protect[s]" the inmates from succumbing to it. Id.

157. 41 Cal. App. 3d 1000, 1003 (1974).

158. Id. at 1011 .

159. Id. at 1011 n.6.

160. Id. at 1013. The judge here is not overtly saying that male nurses would assault patients, but rather that the use of male nurses would subject the hospital to more allegations of sexual assault. The implication that male nurses are more likely to commit assault_or at the very least more plausible perpetrators of assault-in this environment, however, is nonetheless clear.

161. 510 F. Supp. 1191, 1193 (E.D. Ark. 1981), vacated on other grounds, 671 F.2d 1100 (8th Cir. 1982). 
sexual responses prompted by students' exposure to the private body parts of students of the other biological sex." 162

Analogizing judges' reasoning about safety interests in prison and hospital cases to their reasoning about safety interests in the bathroom context is particularly appropriate given judges' ascription of similar characteristics to all of these sex-segregated spaces. In fact, it is the very characteristics that judges suggest bathrooms share with sex-segregated prisons and hospital wards that create a supposedly heightened risk of sexual assault in both contexts. In Long, for example, the judge held that introduction of a female chaplain was inappropriate in part because during her nighttime dormitory checks, the male inmates might "not be particularly modest in their attire or lack of it."163 The men might also engage in private behavior that would "not be desirable or proper in the presence of a woman."164 The judge hints that one of these "undesirable" behaviors might be sexual assault. Indeed, he describes assault as one of the "danger[s]" that any woman "knows ... goes on in a male dormitory." 165 Here, an increased likelihood of nudity, combined with the customary absence of women-features common to sex-segregated bathrooms-increased the risk of sexual assault.

Further, in Backus, male nurses were deemed inappropriate for the obstetrics ward because "labor and delivery nurses perform intimate functions" and even "non-intimate duties ... involve the exposure of the patient's genitalia." 166 The risk of genital exposure is part of the reason that staffing male nurses would require extra precautions "to curb any risk of a molestation charge."167 A heightened risk of genital exposure, which judges urge is also present in bathrooms, ${ }^{168}$ creates an increased danger that sexual assault-or at least plausible allegations of sexual assault-will follow.

Beyond highlighting the parallelism across judges' reasoning in the prison, hospital, and bathroom contexts, cases such as Backus also allow one further refinement of the safety interest at stake in sex-segregated facilities. In addition to an interest in preventing sexual assault itself, judges assert that sex-segregated facilities advance an interest in avoiding allegations of, and liability for, sexual assault. In Everson v. Michigan Department of Corrections, for example, the court cited "allegations of sexual abuse, whether true or not, [which] create a 'poisoned atmosphere""169 as a reason in support of the exclusion of male guards

162. G.G. ex rel. Grimm v. Gloucester Cty. Sch. Bd., 822 F.3d 709, 735 (4th Cir. 2016).

163. 41 Cal. App. 3d 1000, 1010-11 (Ct. App. 1974).

164. Id. at 1011.

165. Id. at 1013 .

166. 510 F. Supp. at $1193,1197$.

167. Id. at 1197.

168. See supra Part II.B.

169. 391 F.3d 737, 753 (6th Cir. 2004). 
from a women's prison. Judges have employed this logic in the bathroom context as well. Remember that the Tenth Circuit held that the "concern" that "the use of women's public restrooms by a biological male could result in liability . . . constitute[d] a legitimate, nondiscriminatory reason" for the termination of Krystal Etsitty. ${ }^{170}$ A Georgia court similarly held that "avoiding the cost of lawsuits, even meritless suits, is a rational legitimate interest" reasonably furthered by "terminating an employee with male genitalia who intends to ... use women's restrooms." 171 Sex segregation in prisons, hospitals, and bathrooms serves an interest not only in preventing sexual assault, it seems, but also in reducing the perceived risk of sexual assault in locations where genital exposure or nudity are ostensibly more likely.

This interest in avoiding allegations of assault can be reframed more generously as an interest in creating spaces where clients will feel saferindependent of whether they actually are safer. This interest, while it resembles the privacy interest in preventing embarrassment or anxiety, is a distinct interest in ensuring that people in potentially sexually vulnerable situations, such as an obstetrics ward, prison, or bathroom, will feel as safe as possible in these situations. Excluding male nurses from an obstetrics ward, for example, may not be a "question [of] the credibility or reliability of a male nurse assisting a male physician during the examination of a female patient," 172 but rather an attempt to ensure that "the birth experience not only be positive but also be without stress." ${ }^{173}$ This attempt to create safe-feeling spaces is reflected in the Michigan Department of Corrections's professed desire to avoid a "poisoned atmosphere" in a women's prison by excluding male guards. ${ }^{174}$ Sex-segregated bathrooms might similarly advance an interest in ensuring that bathrooms feel as safe and stress-free as possible, regardless of whether it actually makes them safer.

Taken together, judges' and litigants' allusions to safety interests in the bathroom context, and judges' more direct discussions of the safety interest in other contexts of sex segregation, suggest that the safety interest supposedly advanced by sex-segregated bathrooms is fundamentally linked to the risk of sexual assault. This larger body of case law suggests that sex-segregated bathrooms serve the safety interests of preventing women from becoming victims of sexual assault and preventing men, driven by unbridled heterosexuality, from committing sexual assault. Further, sex-segregated bathrooms serve the interest of reducing the perception of risk of sexual assault, regardless of whether they reduce actual risk.

170. Etsitty v. Utah Transit Auth., 502 F.3d 1215, 1220 (10th Cir. 2007).

171. Glenn v. Brumby, 724 F. Supp. 2d 1284, 1307 (N.D. Ga. 2010), aff'd, 663 F.3d 1312 (11th Cir. 2011).

172. EEOC v. Mercy Health Ctr., No. CIV-80-1374-W, 1982 WL 3108, at *3 (W.D. Okla. Feb. 2, 1982).

173. Id. at $* 5$.

174. Everson v. Michigan Dep't of Corrections, 391 F.3d 737, 753 (6th Cir. 2004). 


\section{THE LEGAL CASE Against SeX-SEgREgated BATHRoOMS}

Despite a lack of a clear legal challenge to sex-segregated bathrooms, then, judges have nonetheless constructed some legal reasoning behind them. Judges have developed specific interests related to biological difference, privacy, and safety that seem to support a need for sex-segregated bathrooms. But this does not mean that these interests would withstand a direct legal challenge. Sex-based distinctions in the law, including laws and practices mandating sex-segregated bathrooms, are generally subject to intermediate constitutional scrutiny. This Part will explore whether the judicially asserted interests of privacy, safety, and accommodation of biological difference would be sufficient grounds for continued sex segregation of bathrooms in the face of intermediate constitutional scrutiny. ${ }^{175}$

\section{A. The Intermediate Scrutiny Standard}

Generally, laws and policies that expressly classify individuals on the basis of sex are subject to intermediate constitutional scrutiny. ${ }^{176}$ In order to survive intermediate scrutiny, "classifications by gender must serve important governmental objectives and must be substantially related to achievement of those objectives." ${ }^{177}$ Intermediate scrutiny for sex-based classifications arises from the recognition that "our Nation has had a long and unfortunate history of sex discrimination" and that such "discrimination was rationalized by an attitude of 'romantic paternalism' which ... put women, not on a pedestal, but in a cage." 178 Intermediate scrutiny aids courts in invalidating discriminatory laws by allowing judges to look more rigorously at a state's asserted purposes for a classification and at the purported need to use a sex-based classification to achieve those aims. While intermediate scrutiny does not forbid classifications on the basis of gender entirely, it does forbid the use of such classifications "to create or perpetuate the legal, social, and economic inferiority of women." 179

175. This Part will operate under the assumption that laws mandating sex-segregated bathrooms should, indeed, be subject to intermediate scrutiny. Part IV will examine in greater depth whether sexsegregated bathrooms might, in fact, be subject only to rational-basis review.

176. "Because the challenged policy expressly discriminates among applicants on the basis of gender, it is subject to scrutiny under the Equal Protection Clause of the Fourteenth Amendment." Mississippi Univ. for Women v. Hogan, 458 U.S. 718, 723 (1982) (quoting Reed v. Reed, 404 U.S. 71, 75 (1971)); see also Craig v. Boren, 429 U.S. 190, 197 (1976).

177. Craig, 429 U.S. at 197; see also United States v. Virginia, 518 U.S. 515,524 (1996) (holding that "the defender of the challenged action must show 'at least that the classification serves important governmental objectives and that the discriminatory means employed are substantially related to the achievement of those objectives"') (quoting Mississippi Univ. for Women v. Hogan, 458 U.S. 718 , 724 (1982)).

178. Frontiero v. Richardson, 411 U.S. 677, 684 (1973).

179. United States v. Virginia, 518 U.S. 515, 534 (1996). 
The first step in determining whether laws or policies mandating sexsegregated bathrooms are constitutional is determining whether the "government objective" or interest they profess to serve is "important." Indeed, the interest must be "exceedingly persuasive."180 Any justification for employing a suspect classification "must be genuine, not hypothesized or invented post hoc in response to litigation."181 The classification "must not rely" on "overbroad generalizations about the different talents, capacities, or preferences of" certain groups, ${ }^{182}$ even when these generalizations "enjoy empirical support."183 Intermediate scrutiny forbids interests that rely on stereotypes, and any "statutory objective" that "itself reflects archaic and stereotypic notions ... is illegitimate." 184 An interest in "exclud[ing] or 'protect[ing]' members of one gender because they are presumed to suffer from an inherent handicap or to be innately inferior," for example, is not a legitimate interest under intermediate scrutiny. ${ }^{185}$

Assuming the state can assert an important interest in segregating bathrooms by sex, the second step in an intermediate-scrutiny evaluation is determining whether sex-segregated bathrooms are "substantially related" to achieving that interest. The substantial-relation requirement prevents states from employing the "simplistic, outdated assumption that gender could be used as a "proxy for other, more germane bases of classification." 186 The "tighter fit between means and ends" required by intermediate scrutiny provides that "the availability of sexneutral alternatives to a sex-based classification is often highly probative of the validity of the classification." 187 Thus, a state may not merely assert that sex segregation in bathrooms serves an important interest. It bears the higher burden of showing that sex segregation actually serves that interest better than other, gender-neutral alternatives would. ${ }^{188}$

180. Id. at 524 (quoting Hogan, 458 U.S. at 724 ).

181. Id. at 533 .

182. Id.

183. Tuan Anh Nguyen v. I.N.S., 533 U.S. 53, 76 (2001).

184. Hogan, 458 U.S. at 724.

185. Id.

186. Hogan, 458 U.S. at 726.

187. Nguyen, 533 U.S. at 78.

188. "[T]he burden of justification is demanding and it rests entirely on the State." United States. v. Virginia, 518 U.S. 515,533 (1996). 


\section{B. Applying Intermediate Scrutiny to the Judicially Asserted Interests}

\section{Accommodating Biological Differences}

An evaluation of the alleged biological differences that sex-segregated bathrooms might "accommodate" is an important first step in determining whether bathrooms serve any constitutionally permissible interest. "Real" biological differences have in fact served as an important limit on the Supreme Court's sex-equality jurisprudence. Generally, the Court has upheld laws under intermediate scrutiny when it perceives those laws to be founded on "actual differences between men and women, as opposed to stereotypes of differences." 189 In United States v. Virginia, for example, Justice Ginsburg wrote that while "supposed 'inherent differences' are no longer accepted as a ground for race or national origin classifications ... [p]hysical differences between men and women" might justify differential treatment. ${ }^{190}$ In Nguyen $v$. INS, the Court upheld a sex-based distinction in immigration law based on such a "biological difference" between men and women, namely women's unavoidable presence at childbirth. ${ }^{191}$ If sex-segregated bathrooms accommodate real biological differences, then, they could be found to be constitutional.

Sex segregation in bathrooms, however, does not accommodate any real biological differences: even if we take biological difference for granted (pretending, for instance, that transgender or intersex people do not use the bathroom) it is not obvious that biological difference should lead to sex segregation. As Erving Goffman has noted, while "the functioning of sexdifferentiated organs is involved," when we use the bathroom, "there is nothing in this functioning that biologically recommends segregation." "192 This should be readily apparent to any person who has used a restroom in a private home- - such facilities accommodate both men and women every day. This is also true of unisex single-stall public facilities. When the district court judge in the G.G. case suggested that "[r]estrooms ... are designed differently because of the biological differences between the sexes," the only evidence he pointed to was the fact that

189. Cohen, supra note 47, at 104 (providing many examples of the court allowing for "real" differences between men and women in the law). See also CATHARINE MaCKINNON, TOWARDS A FEMINIST THEORY OF THE STATE 216 (1989) ("Difference defines the state's approach to sex equality .... The deepest issues of sex inequality, in which the sexes are most constructed as socially different, are either excluded at the threshold or precluded from coverage once in. In this way, difference is inscribed on society as the meaning of gender and written into law as the limit on sex discrimination.")

190. United States v. Virginia, 518 U.S. at 533.

191. Nguyen, 533 U.S. at 64.

192. Spencer E. Cahill et al., Meanwhile Backstage: Public Bathrooms and the Interaction Order, 14 URBAN LIFE 33, 54 (1985). 
"[m]ale restrooms . . contain urinals, while female restrooms do not." ${ }^{, 193}$ Yet urinals are clearly not a biological necessity; they are—as the judge admits—a "convenience." 194

Even this claim to "convenience" stems from stereotypes about biological difference rather than from biological differences themselves. While many men do prefer urinals, other men have medical conditions, such as parureris, or "shy bladder syndrome," that turn urinals into a substantial barrier to public restroom use. ${ }^{195}$ Other men simply find urinals embarrassing. ${ }^{196}$ Even if men's preference for urinals were biologically immutable, the sex segregation of restrooms would not be substantially related to accommodating this need. There is nothing biological preventing urinals and toilets from being made available in the same unisex bathroom. ${ }^{197}$

Other notions of "biological difference" supporting sex segregation more obviously rely on stereotypes. Some opponents of increasingly prevalent unisex bathrooms, for example, suggest that sex-segregated bathrooms are essential because men are inherently dirtier. ${ }^{198}$ The link to biology appears to be that "men stand to urinate and at times might not aim accurately." 199 If it is not clear on its face that such claims rely on stereotypes about the "talents, capacities, or

193. G.G. ex rel. Grimm v. Gloucester Cty. Sch. Bd., 132 F. Supp. 3d 736, 750 (E.D. Va. 2015), rev'd in part, vacated in part, 822 F.3d 709 (4th Cir. 2016) (citations omitted).

194. Id.

195. As many as " 17 million Americans, or about 7 percent of the U.S. population," suffer from some degree of paruresis. Ninety percent of those who seek treatment are male. Urinals can present significant barriers to using public restrooms for these men. STEVEN SOIFER ET AL., SHY BLADDER SYNDROME: YOUR STEP-BY-STEP GUIDE TO OVERCOMING PARURESIS 6-7 (2001).

196. One psychologist has written, for example, that "[a]gain and again over the years, and not in small numbers, men have confided to me that they find urinals anxiety-provoking-even humiliating." Keith Ablow, What Men Really Think About Urinals, Fox News, May 6, 2011, http://www.foxnews .com/health/201 1/05/06/men-really-think-urinals.html [https://perma.cc/N5VG-MNCN].

197. Indeed, many public men's restrooms contain both urinals and unisex toilets. That these facilities are not seen to accommodate both men and women is a matter of privacy-due to a lack of stalls around urinals - rather than biology. See discussion infra Part III.B.ii.

198. See, e.g., Charlotte Allen, Privacy Down the Toilet, NAT. REv., Nov. 3, 2014, https://www .nationalreview.com/nrd/articles/390465/privacy-down-toilet [https://perma.cc/CJK5-QG5M] ("Women are simply more fastidious than men about the physical circumstances in which we do our business. We highly value cleanliness and privacy.").

199. Ian Ayres, Looking Out for No. 2: A Modest Proposal for Single-Use Toilets, SLATE, Mar. 7, 2005, http://www.slate.com/articles/news_and_politics/jurisprudence/2005/03/looking_out_for_no_2.ht $\mathrm{ml}$ [https://perma.cc/MP5Z-ZP4C]. 
preferences" of men and women, ${ }^{200}$ both anecdotal ${ }^{201}$ and scientific ${ }^{202}$ evidence demonstrates that women's restrooms are often dirtier than men's restrooms. Another biology-linked claim sometimes invoked to defend sex-segregated bathrooms is the fact that women take longer to use the restroom. While evidence does suggest that women spend longer in the bathroom, ${ }^{203}$ evidence also suggests that this has as much to do with social factors-such as women's apparel, ${ }^{204}$ the awkwardness of toilet stalls, and women's responsibility for children in the bathroom ${ }^{205}$ - than with biology. Even if biology were the single driving factor behind cisgender women's relative longer times in the restroom, sex-segregated bathrooms would seem to exacerbate this problem by inefficiently isolating the "slowest" users from the "fastest" users. ${ }^{206}$

In conclusion, accommodating biological differences should not be considered an important state interest, largely because these "differences" are often based on stereotypes rather than reality. Even if the differences do exist, sex segregation is not substantially related to accommodating them. Indeed, segregation often exacerbates inequities in access for women. As such, an interest in accommodating biological difference almost certainly fails intermediate scrutiny, which perhaps explains why judges almost never assert this interest. Ultimately, while biological differences might seem a "common sense" answer to why bathrooms should be sex-segregated, it is clear that "[a]t the heart of the issue are not the genitalia themselves of the users, nor the differences between male and female genitalia, but rather the significance of the

200. "The deeper justification must be not only that some men are messy but that men as a class aren't as sensitive as women are to the messiness. But this is just the type of unsupported sexual stereotyping that our discrimination law was meant to stop." Id.

201. Mary Schimich, Sharing Bathroom with Men Raises Question of Cleanliness, CHI. TRIB., Jan. 29, 2016, http://www.chicagotribune.com/news/columnists/schmich/ct-gender-neutral-bathroom-mary -schmich-0129-20160128-column.html [https://perma.cc/ELD6-NMAN] (describing interviews with professional cleaners who reported the "women's room, hands down," as dirtier than the men's room).

202. Wendy Marston, Scientist at Work: Charles Gerba; On Germ Patrol, at the Kitchen Sink, N.Y. TIMES, Feb. 23, 1999, http://www.nytimes.com/1999/02/23/health/scientist-at-work-charles-gerbaon-germ-patrol-at-the-kitchen-sink.html [https://perma.cc/VN26-D8DQ] ("He discovered which sex had dirtier bathrooms (women, by far) ....").

203. Case, supra note 70, at 213 . ("Studies carried out by researchers do offer some statistics in support of the assumption that women take longer ... in the restroom.").

204. Id. ("Whereas pantyhose slow women down, for example, the zipper front and center on a typical pair of pants only facilitates male urination.").

205. Clara Greed, Creating a Nonsexist Restroom, in TOILET: PUBLIC RESTROOMS AND THE POLITICS OF SHARING 117, 119 (Harvey Moltoch \& Laura Noren eds., 2010).

206. Case, supra note 70, at 218 ("Basic queuing theory confirms that making fully enclosed single-user facilities available to either sex on demand, as airplane toilets are, would cut down on overall waiting times and promote the most efficient use of available toilet facilities."). Sex segregation has often, in fact, operated to ensure that the "slowest" users have the fewest facilities to use: "Even if the floor space provided for the ladies' and men's rooms is of equal size, men are likely to have twice the places to pee because they will have stalls plus a row of urinals along the wall-hence the queues, where women patiently stand in line." $I d$. at 118 . 
genitalia in social and political terms."207 Included in this social meaning are privacy and safety concerns, to which this Note now turns.

\section{Privacy}

If the sex segregation of bathrooms is intended to protect a general privacy interest, it is doing a very poor job of it. Sex-segregated public restrooms generally fail to protect one's privacy from members of the same sex, and we generally do not expect them to. ${ }^{208}$ As they are currently designed, restrooms are a place where people cannot avoid becoming aware of others' bodily functions, or having others become aware of their bodily functions, through sight, sound, and smell. This is particularly true for people who use urinals. A generalized, gender-neutral privacy interest, even if "important," would thus provide little support for sex segregation of bathrooms. As discussed supra in Part II, however, the privacy interest that judges assert in support of sex-segregated bathrooms is not as expansive as this. Rather, it is a specific interest in avoiding the embarrassment, stress, or shame caused by unwanted exposure of one's body or bodily functions to members of the opposite sex-or exposure to such bodies and functions. This Note argues, however, that this interest still does not justify sex-segregated bathrooms in the face of intermediate scrutiny, even for cisgender people, primarily because the interest relies on mere stereotypes about men and women.

A state asserting that bathrooms protect a privacy interest that exists only in relation to the "opposite sex" is necessarily asserting that there will be greater embarrassment, stress, or shame caused by exposure of one's body or bodily functions to members of the opposite sex than to members of one's own sex. Part of this claim, as hinted at by Judge Niemeyer's allusion to potential "sexual responses prompted by students' exposure to the private body parts of students of the other biological sex," 209 is undoubtedly rooted in notions of sexuality. ${ }^{210}$ While different genitalia themselves may not demand segregation, perhaps heterosexuality does. As one scholar has framed it, sex-segregated bathrooms might protect privacy by allowing one to "shield[] oneself, during the

207. Overall, supra note 16 , at 75.

208. See Susan E. Keller, Operations. of Legal Rhetoric: Examining Transsexual and Judicial Identity, 34 HARV. C.R.-C.L. L. REV. 329, 370 (1999). ("[T] he term "public restroom" is something of an oxymoron . . . because one is required to share it with others, a public or workplace restroom is someplace where one has a limited expectation of privacy.").

209. G.G. ex rel. Grimm v. Gloucester Cty. Sch. Bd., 822 F.3d 709, 735 (4th Cir. 2016) (Niemeyer, J., concurring in part and dissenting in part).

210. As one scholar has suggested, the sex segregation of bathrooms seems to advance an interest in "the maintenance of that sense of mystery or forbiddenness about the other sex's sexuality ...." Antony, supra note 92, at 5 (quoting Richard Wasserstrom, Racism, Sexism, and Preferential Treatment: An Approach to the Topics, 24 UCLA L. REV. 581, 594 (1977), excerpted in PHILOSOPHY AND WOMEN 5, 10 (Sharon Bishop \& Marjorie Weinzweig eds., 1979)). 
performance of elimination, from members of the group of individuals to whom one is, was, or will be sexually attracted and with whom one might ordinarily engage in or want to engage in or once have engaged in sexual activities."211

This reasoning, however, does not hold up to any real scrutiny. Even if a state has an important interest in helping people maintain their sexual allure by preventing others from becoming aware of their bodily functions, sex segregation is not substantially related to achieving this end for many people. While a majority of people are sexually attracted to members of the opposite sex, many are sexually attracted to members of the same sex. Positing that sex segregation solves the problem of sexuality-related embarrassment in the bathroom relies on assumptions of heterosexuality ${ }^{212}$ and thus "overbroad generalizations about the ... preferences of" men and women. ${ }^{213}$ Indeed, if we accepted that bathrooms served an important privacy interest in preventing sexuality-based embarrassment, single-sex bathrooms would constitute a gross privacy violation for those attracted to members of the same sex. The fact that "lesbians and gay men manage to use sex-segregated toilets," despite the possibility of being sexually interested in someone they share the bathroom with, reveals that a privacy interest based on sexuality is not so important. ${ }^{214}$

Some might object that sex-segregated restrooms' failure to serve the sexuality-linked privacy concerns of gay and lesbian individuals does little to undermine their substantial relation to sexuality-linked privacy concerns more generally. Most courts, including the Supreme Court, have not endorsed a constitutional theory of sex discrimination that forbids discrimination on the basis of sexual orientation. Even as it struck down a law targeting gay, lesbian, and bisexual individuals in Romer v. Evans, for example, the Supreme Court did so under a rational-basis review rather than under heightened scrutiny. ${ }^{215}$ Neither Windsor nor Obergefell, both Supreme Court cases that extended marriage equality to sexual minorities, did so on the grounds that discrimination on the basis of sexual orientation is a form of sex discrimination. ${ }^{216}$ As such, sex-

211. Overall, supra note 16 , at 80 .

212. "The separation [of women's and men's bathrooms] ignores same-sex sexuality .... [W] and men's bathrooms assume heterosexuality and the existence of only two sexes ...." Patricia Cooper \& Ruth Oldenziel, Cherished Classifications: Bathrooms and the Construction of Gender/Race on the Pennsylvania Railroad During World War II, 25 FEMINIST STUD. 7, 26 (1999).

213. United States v. Virginia, 518 U.S. 515,533 (1996).

214. Overall, supra note 16 , at 80 (explaining that if sexuality were a vital part of the privacy interest protected by bathrooms, "current toilet arrangements are, for lesbians and gay men, mightily inconvenient and inappropriate" and noting that "[n]onetheless, lesbians and gay men manage to use sex-segregated toilets.").

215. 517 U.S. 620, 631 (1996).

216. Obergefell v. Hodges, 135 S. Ct. 2584, 2603-05 (2015) (identifying the exclusion of same-sex couples from marriage as a violation of mutually dependent liberty and equality interests rather than as a form of sex-based discrimination); United States v. Windsor, $133 \mathrm{~S}$. Ct. 2675, 2693-96 (2013) (striking down the Defense of Marriage Act on the grounds of evidence of animus and unconstitutional interference with liberty interests rather than of improper sex-based discrimination). 
segregated restrooms' reliance on assumptions of heterosexuality might not be of concern in a constitutional sex-discrimination analysis.

Recent litigation in the Title VII context, however, suggests that courts are beginning to understand discrimination on the basis of sexual orientation as a form of sex discrimination. Last year, for example, the Seventh Circuit held that employment "discrimination on the basis of sexual orientation is a form of sex discrimination" prohibited by Title VII. ${ }^{217}$ The court relied in part on the theory that discrimination on the basis of sexual orientation fundamentally relies on sexbased stereotypes: "[the lesbian plaintiff] represents the ultimate case of failure to conform to the female stereotype (at least as understood in a place such as modern America, which views heterosexuality as the norm and other forms of sexuality as exceptional): she is not heterosexual." 218 The EEOC has endorsed a similar theory of sexual-orientation discrimination as sex discrimination since $2015,{ }^{219}$ and the Chief Judge of the Second Circuit asserted this same theory in a recent Title VII case. ${ }^{220}$

Although Title VII analysis is distinct from constitutional sex-discrimination analysis, these courts provide a theory for understanding presumptions of heterosexuality as constitutionally forbidden sex-based stereotypes and "overbroad generalizations about the ... preferences of" men and women. 221 Justice Kennedy's assertion in Obergefell that our constitutional order can evolve to encompass broader protections for sexual minorities suggests that courts may increasingly understand assumptions about heterosexuality as at odds not only with Title VII, but also with the Constitution's prohibition of sex discrimination. The Eleventh ${ }^{222}$ and Seventh ${ }^{223}$ Circuits, for example, have already moved towards a more expansive understanding of constitutional sex discrimination, recently holding that discrimination against transgender individuals is subject to heightened scrutiny as a form of sex discrimination. At the very least, evidence of courts' broadening understanding of protections for gender and sexual minorities-and of what constitutes sex discrimination forbidden by the Constitution-supports a modest point: assumptions about heterosexuality alone

217. Hively y. Ivy Tech Cmty. Coll. of Indiana, 853 F.3d 339, 341 (7th Cir. 2017).

218. Id. at 346.

219. Baldwin v. Dep't of Transp., EEOC Appeal No. 0120133080 (July 15, 2015) (asserting, in part, that discrimination on the basis of sexual orientation is sex-based discrimination because it represents discrimination based on gender stereotypes about which kinds of people men and women should be romantically attracted to).

220. Christiansen v. Omnicom Grp., Inc., 852 F.3d 195 (2d Cir. 2017) (Katzmann, C.J., concurring).

221. United States v. Virginia, 518 U.S. 515,533 (1996).

222. In Glenn v. Brumby, the Eleventh Circuit held that discrimination against transgender employees constitutes sex-based discrimination under the Constitution and is thus "subject to heightened scrutiny under the Equal Protection Clause." 663 F.3d 1312, 1319 (11th Cir. 201.1).

223. Whitaker v. Kenosha Unified Sch. Dist., No. 16-3522 (7th Cir. 2017) (finding that transgender discrimination is subject to heightened constitutional scrutiny as per-se sex-based discrimination). 
are shaky ground for the overt sex-based discrimination presented by sexsegregated restrooms.

Judges' assertions that people have a special privacy interest against the opposite sex, however, certainly do not rely on sexuality alone. They more often rest on cultural norms. As one court put it, "exposure of [the] nude body and bodily functions ... within the perceptive range of strangers of the opposite sex . . . clashes with a deeply held social, moral and emotional bias pervading Western culture." ${ }^{224}$ As another urged, a heightened need for privacy around the opposite sex is "a cultural thing." ${ }^{225}$ Because of the ubiquity of "segregated toilet facilities in public places which children are early taught to use," Americans have developed a greater need for privacy in the presence of the opposite sex, and " $[t]$ he fact that a need for privacy is the product of social conditioning makes it no less embarrassing or occasions no less feeling of shame." ${ }^{.226}$ As Judge Posner poignantly urged in his dissent to Johnson $v$. Phelan, failing to respect this social "reality" may fail to respect individuals' very humanity. ${ }^{227}$ It is this cultural and psychological violation that also seemed to animate the Carcaño court's conjuring of the 12-year-old girl exposed to "mature" "male genitalia." 228 Thus, even if there are no biological or sexual differences that produce an important sex-specific privacy interest, perhaps there are important social differences that do.

Acknowledging cultural realities, however, does not mean accepting that protecting people from the embarrassment of exposure to members of the opposite sex is an important government interest for the purposes of intermediate scrutiny. The Second Circuit articulated this idea when it struck down a statute barring women from exposing their breasts in public: "[a]lthough protecting public sensibilities is a generally legitimate goal for legislation, ... it is a tenuous basis for justifying a legislative classification that is based on gender, race or any other grouping that is associated with a history of social prejudice."229 Indeed, this is why sex-based classifications are subject to heightened, rather than rational-basis, scrutiny. Our sex-discrimination jurisprudence recognizes that cultural norms often "reflect[] archaic and stereotypic notions" that are usually not a legitimate basis for laws that discriminate between men and women. ${ }^{230}$

224. In re Long, 127 Cal. Rptr. 732, 736 (Ct. App. 1976).

225. Local 567 Am. Fed'n of State, Cty., \& Mun. Employees v. Michigan Council 25, Am. Fed'n of State, Cty., \& Mun. Employees, 635 F. Supp. 1010, 1014 n.7 (E.D. Mich. 1986).

226. Forts v. Ward, 471 F. Supp. 1095, 1098 (S.D.N.Y. 1978), vacated in part, 621 F.2d 1210 (2d Cir. 1980).

227. Johnson v. Phelan, 69 F.3d 144, 155 (7th Cir. 1995) (Posner, J., concurring in part and dissenting in part).

228. Carcaño v. McCrory, 203 F. Supp. 3d 615, 644 (M.D.N.C. 2016) (internal citation omitted).

229. People v. Santorelli, 600 N.E.2d 232, 236 (N.Y. 1992) (internal citations omitted).

230. Mississippi Univ. for Women v. Hogan, 458 U.S. 718, 725 (1982). 
In other words, while a culturally derived privacy interest might be enough to sustain a non-suspect classification, it is likely not enough to support sexsegregated bathrooms. The Supreme Court rejected just this kind of interest in United States $v$. Virginia. There, VMI tried to argue that "female participation in VMI's adversative training 'would destroy ... any sense of decency that still permeates the relationship between the sexes." 231 Justice Ginsburg quickly dispatched this concern as "an ancient and familiar fear" that has been used to perpetuate women's exclusion, and as insufficient to sustain VMI's male-only admissions policy. ${ }^{232}$ Justice Ginsburg is correct-arguments about cultural propriety and embarrassment have been used to justify now-archaic sex-based segregation in many places, such as swimming pools ${ }^{233}$ and bars. ${ }^{234}$

Even if we did not have historical reasons to doubt cultural privacy norms as an important reason for segregating the sexes, we may doubt their ubiquity today. Many people do not feel their privacy is invaded by the presence of the opposite sex in the bathroom, demonstrating the degree to which sex segregation relies on "overbroad generalizations about the ... preferences of' men and women. ${ }^{235}$ People with disabilities, for example, may daily use the restroom with the assistance of an opposite-sex attendant. ${ }^{236}$ Parents with children of a different sex often bring these children into the bathroom with them without raising privacy concerns. ${ }^{237}$ Even if most people might prefer extra privacy from the "opposite" sex in restrooms, U.S. v. Virginia held that "estimates of what is appropriate for most women" or "most men" are not important enough to sustain sex-based discrimination in law. ${ }^{238}$

The existence of people who feel that their privacy is invaded by observation by members of the same sex further undercuts the importance of the oppositesex privacy interest. Recognizing that some people might become anxious at the prospect of any maintenance person entering a restroom or locker room while they are using it demonstrates just how tenuous - if not overtly harmful - a sexspecific privacy interest really is. This revelation is perhaps best illustrated by a return to Judge Posner's dissent in Johnson v. Phelan. In his dissent, Judge

231. United States v. Virginia, 518 U.S. 515, 528 (1996) (quoting United States v. Virginia, 44 F.3d 1229, 1239 (4th Cir. 1995)) (alteration in original).

232. Id. at 555 n. 20 .

233. Brief of NAACP Legal Defense and Educational Fund et al. as Amicus Curiae in Support of Respondent, Gloucester Cty. Sch. Bd. v. G.G. ex rel. Grimm, 137 S. Ct. 369 (2016) (No. 16-273) ("Because of [a] combination of factors-bodily exposure, physical contact, and difficulty of surveillance-public officials demanded that males and females swim separately.") (quoting JEFF WILTSE, CONTESTED WATERS: A SOCIAL HISTORY OF SWIMMING POOLS IN AMERICA 2 (2007)).

234. Hickey, supra note 51, at 382 (describing how cultural norms, notions of privacy, and "common sense" were all used as justifications for the maintenance of male-only bars and clubs).

235. U.S. v. Virginia, 518 U.S. at 533.

236. Gershenson \& Penner, supra note 22, at 7.

237. Id.

238. U.S. v. Virginia, 518 U.S. at 550. 
Posner goes to great lengths to scapegoat "radical feminists"" and their "blind" pursuit of equality as driving the psychologically traumatizing surveillance of a deeply vulnerable group of people-incarcerated individuals. ${ }^{239}$ If feminists respected socially-derived opposite-sex privacy interests, the argument goes, prisoners would no longer experience such drastic invasions of privacy.

This opinion's staunch focus on the indignity of opposite-sex observation, however, obscures the fundamental privacy issue at stake in this case-pervasive surveillance of any kind. As Judge Posner notes, "to place male prisoners under continuous visual surveillance by female guards... so that whenever the prisoner dresses or undresses, takes a shower, or uses the toilet, a woman is watching him, gives even my colleagues pause." 440 Yet, replacing "female" and "woman" with "male" and "man" in this sentence-Judge Posner's solution to this indignity - seems no less worthy of pause. Suggesting that the provision of same-sex guards would remedy the privacy concerns at stake in this case clearly "underestimate[s] the extent to which observation and surveillance are their own manifestations of power, regardless of the sex of the participants." 241 If oppositesex observation is really cruel and unusual under these conditions, it is difficult to understand how same-sex observation under the same conditions is entirely acceptable.

Fundamentally, Posner's superficial solution to the privacy problem presented in Phelan - sex-segregated prison guards - demonstrates the degree to which alleged opposite-sex privacy interests often undercut more general privacy needs. It is only a single-minded focus on sex-specific privacy that allows sex segregation to appear a plausible solution to problems that cannot possibly be solved by segregation alone. It is this narrow focus that causes litigants to balk at the notion of an adult forcibly exposing himself to a 12-year-old girl but not to a 12-year-old boy. This double standard applies in even the most "extreme" prison scenarios, such as body-cavity searches by guards. By focusing on the sex of the searcher as the defining factor of whether a search violates prisoners' privacy, judges avoid the far more significant question of whether searches by guards-rather than, say, by medical professionals-are appropriate at all. This applies in more benign scenarios as well, such as hospital wards, where focusing on the sex of nurses or doctors can obscure factors far more important to privacy, such as consent. ${ }^{242}$ Culturally or "reality"-based opposite-sex privacy interests

239. Johnson v. Phelan, 69 F.3d 144, 152, 155 (7th Cir. 1995) (Posner, J., concurring in part, dissenting in part).

240. Id. at 154.

241. Sharon M. McGowan, The Bona Fide Body: Title VII's Last Bastion of Intentional Sex Discrimination, 12 COLUM. J. GENDER \& L. 77, 101 (2003).

242. As Amy Kapczynski has suggested, "Patients may have an underlying privacy right not to be exposed to the view of others, particularly nonmedical personnel, without their consent, but once again, consent is primary, and sex plays no legally decisive role in the matter." Amy Kapczynski, Same-Sex Privacy and the Limits of Antidiscrimination Law, 112 YALE L.J. 1257, 1269 (2003). 
are therefore likely to undercut privacy as a general matter. Although they are often framed as common-sense appeals to our very humanity, opposite-sex privacy interests are ultimately too weak a concept to support differential treatment based on sex.

Without biology, sexuality, or culture producing an important sex-specific privacy interest, it is unclear what important privacy interest sex segregation of bathrooms do serve. Even if a state could successfully establish an important sexspecific privacy interest, however, sex-segregated bathrooms should nonetheless fail under the substantial-relation prong of intermediate scrutiny. Remember that the judicially constructed privacy interest in bathroom segregation seeks to prevent embarrassment arising from two risks: bodily exposure and bodilyfunction exposure. Sex-neutral alternatives to bathroom segregation could do an equally good, if not better, job of preventing both of these risks. As the Supreme Court has articulated, "the availability of sex-neutral alternatives to a sex-based classification is often highly probative of the validity of the classification." 243 In other words, it does not matter if there is a heightened privacy interest against the other sex when this interest could be equally served by a gender-neutral solution.

As for the first privacy interest, the interest in preventing bodily exposure, this risk is already essentially absent from women's restrooms. The existence of stalls, which prevent all people from seeing each other in states of undress, means that women's rooms could already be cheaply converted into unisex restrooms. The risk of exposure in men's rooms, generated by urinals, could easily be remedied by the placement of additional stalls around urinals. Co-ed bathrooms designed much in this way already pervade university campuses. ${ }^{244}$ Integrated bathrooms with this level of privacy might in fact be welcome to many men, such as those with shy bladder syndrome, who desire increased privacy. ${ }^{245}$

Some might object that this design would not successfully preserve privacy because people - particularly men - might attempt to look over or under stalls. Further, open stalls would not protect people from the second privacy risk of exposing bodily functions to others through sound or smell. But even this punctilious notion of privacy could be remedied by the introduction of floor-toceiling stalls. Bathrooms using floor-to-ceiling stalls are already the norm in

243. Tuan Anh Nguyen v. I.N.S., 533 U.S. 53, 78 (2001).

244. See Anthony \& Dufresne, supra note 33, at 282-83 (naming some educational institutions with bathrooms designed this way); Francesca Gaibi, Most People Have All-Gender Restrooms at Home. Why Not Have Them Everywhere?, TRUTHOUT, Dec. 9, 2016, http://www.truth-out.org/opinion/item /38679-most-people-have-all-gender-restrooms-at-home-why-not-have-them-everywhere (describing more contemporary institutional additions to the movement). The author of this Note used one such facility as an undergraduate at Yale University.

245. Case, supra note 70, at 217 ("Ending sex segregation in the toilets need not mean a loss of privacy for women. It could instead offer increased privacy to men, something that could appeal at least to those men who suffer from pee-shy, a pathological inability to urinate easily when at risk of being observed, as at the urinals in a public toilet."). 
many European countries ${ }^{246}$ and are becoming increasingly common in many places in the United States, including restaurants, clubs, and art galleries. ${ }^{247}$ While redesigning extant facilities to meet these requirements might be costly, cost has generally not been a successful defense of sex discrimination in Title VII cases, and the ADA has already required institutions to incur significant costs to prevent discrimination. ${ }^{248}$ Further, with respect to new buildings, genderneutral bathrooms are often cheaper to build than separate restrooms and so could actually save money. ${ }^{249}$

Finally, the fact that gender-neutral solutions would better serve privacy interests than sex-segregated bathrooms is the strongest refutation of judges' appeals to social "reality" as a reason for maintaining sex-segregated facilities in general. While judges such as Judge Posner would pit feminists' push for sex equality against the needs of vulnerable individuals such as prisoners, genderneutral solutions that promote both equality and privacy undermine this attempt to scapegoat sex equality. Certainly, being observed while changing or using the toilet is troubling to many people. Many men might be sincerely troubled by the prospect of a maintenance person bursting into the bathroom unexpectedly while they are at a urinal. Many parents might be nervous about an adult exposing themselves to their child in the bathroom. What is troubling about these scenarios, however, has little to do with sex and much more to do with privacy as a general matter. Abandoning notions that sex segregation is the exclusive, or even the most effective, means of addressing such privacy concerns allows us to address privacy concerns with solutions that are far more responsive to reality.

Therefore, sex-segregated bathrooms, if premised only on privacy concerns, should not pass intermediate scrutiny. This is true when the asserted privacy interest is general and particularly true when it is sex-specific. Stereotypes about biological or sexual differences, as well as stereotypes about men and women's social preferences, cannot form the foundation of an important state interest. Even if there were an important sex-specific privacy interest, the availability of practical, sex-neutral alternatives reveals that sex segregation is not substantially related to that interest.

246. Overall, supra note 16 , at 80.

247. Joel Sanders \& Susan Stryker, Stalled: Gender-Neutral Public Bathrooms, 115 S. ATLANTIC Q. 779 , 783 (2016) (describing the design and use of gender-neutral bathrooms in a number of places in the United States, including in the New York Museum of Modern Art).

248. See Sarah A. Moore, Facility Hostility? Sex Discrimination and Women's Restrooms in the Workplace, 36 GA. L. REV. 599, 627-28 (2002).

249. Anthony \& Dufresne, supra note 33, at 287 ("[P]lanners and city officials should view free-standing, gender-neutral, unisex restrooms as potential cost savers compared to traditional gender-segregated design. When well planned, designed, managed, and maintained, they can save strapped city budgets considerable funds."). 


\section{Safety}

Outside of privacy, protecting safety is the most plausible interest justifying sex-segregated bathrooms. As with privacy, however, the importance of this safety interest is undermined by the fact that it is sex-specific. Remember that judges assert sex segregation not as a means of protecting safety generally, but instead as a means of preventing a particularly gendered form of sexual assault. Judges seem to suggest that sex segregation helps prevent women from becoming victims of, and men from perpetrating, sexual assault.

Fundamentally, a safety interest in protecting only women from sexual assault relies on impermissible stereotypes about men and women. Indeed, the Supreme Court used such women-protective arguments as a quintessential example of an interest that "reflects archaic and stereotypic notions" in Mississippi University for Women v. Hogan. ${ }^{250}$ The Court asserted that if a state's objective is to "sprotect" members of one gender because they are presumed to suffer from an inherent handicap . . the objective itself is illegitimate." 251 While it may be true, as one judge held, that "[i]t is women who are generally raped, not men," 252 this - as the word "generally" suggests - is a generalization. Studies have estimated that one out of ten victims of rape are male ${ }^{253}$ and that thirty-eight percent of victims of sexual violence are men. ${ }^{254}$ Rates of sexual assault among men are still higher among young men and boys. ${ }^{255}$ While the exact numbers vary depending on the study and methodology, men and boys clearly can be and often are victims of sexual assault. Studies also show that men are not the only perpetrators of sexual assault. ${ }^{256}$

Evidence thus demonstrates that an interest in protecting women alone from sexual assault by a presumptively male assaulter relies on nothing more than stereotypes that women are sexually assaulted while men are not, and that men commit sexual assault while women do not. ${ }^{257}$ Even if the risk of sexual assault

250. Mississippi Univ. for Women v. Hogan, 458 U.S. 718, 725 (1982).

251. Id.

252. Long v. State Pers. Bd., 41 Cal. App. 3d 1000, 1011 n.6 (1974).

253. Victims of Sexual Violence: Statistics, RAINN, https://www.rainn.org/statistics/victims-sexualviolence [https://perma.cc/TZM3-L5GN] (last visited Dec. 9, 2017).

254. Conor Friedersdorf, The Understudied Female Sexual Predator, ATLANTIC, Nov. 28, 2016, https:// www.theatlantic.com/science/archive/2016/11/the-understudied-female-sexual-predator $/ 503492$ [https://perma.cc/3BT2-X4J5]; Hanna Rosin, When Men Are Raped, SLATE, Apr. 29, 2014, http://www.slate.com/articles/double_x/doublex/2014/04/male_rape_in_america_a_new_study _reveals_that_men_are_sexually_assaulted.html [https://perma.cc/7 $\overline{\mathrm{F} Z \mathrm{X}}-\mathrm{VP} 6 \mathrm{~B}]$.

255. NAT'L SeXual Violence Res. CtR., STATistics ABOUt SeXual Assault (2015), available at http://www.nsvrc.org/sites/default/files/publications_nsvrc_factsheet_media-packet_statisticsabout-sexual-violence_0.pdf [https://perma.cc/QPA $\overline{8}-A Y P \bar{E}]$.

256. See Friedersdorf, supra note 254 (describing a number of studies demonstrating evidence that women commit a significant number of sexual assaults against men).

257. For a discussion of courts' stereotypical treatment of women's "rapability," see MACKINNON, supra note 189 , at 226 . 
is greater for women, "overbroad sex-based generalizations are impermissible" as a basis for legislation "even when they enjoy empirical support." ${ }^{258}$ Further, the Supreme Court has suggested in other contexts that stereotypes about women's sexual vulnerability as justification for segregation are insufficient in the face of constitutional scrutiny. ${ }^{259}$ Extensive Title VII precedent, holding that generalized concerns about women's safety are not an acceptable basis for denying women jobs, further weighs in favor of this conclusion. ${ }^{260} \mathrm{An}$ interest in women's safety from sexual assault is thus unlikely to support sex segregation in bathrooms, even if women generally are more sexually vulnerable than men.

The interest in avoiding allegations of, or liability for, sexual assault fares no better as an important justification for sex segregation. Admittedly, this interest does not necessarily rely on stereotypes about men and women's relative sexual vulnerability or aggression; an employer might think male employees are no more dangerous than female ones but still exclude them in the name of creating a safe space for women who feel less safe around men. ${ }^{261}$ Nonetheless, such liability avoidance or safe space-protective interests rely on alternative stereotypes about men and women's comfort in sex-integrated facilities. These stereotypes resemble those which insufficiently support an opposite-sex privacy interest-namely, that women feel "safer" around other women as a matter of sexuality, culture, or biology. ${ }^{262}$

The Eleventh Circuit, for this reason, looked dubiously upon the importance of the imputed comfort of customers when an employer attempted to use it as a reason for firing a transgender employee. ${ }^{263}$ The court urged that while

258. Tuan Anh Nguyen v. I.N.S., 533 U.S. 53, 76 (2001).

259. In Craig v. Boren, 429 U.S. 190, 210 n.23 (1976), for example, the Court overruled Goesaert v. Cleary, 335 U.S. 464 (1948), which had upheld a Michigan law that forbade women, other than wives and daughters of the male bar owners, from working in the male spaces of bars. In doing so the Court rejected Michigan's reasoning that such a law was justified because "the oversight assured through ownership of a bar by a barmaid's husband or father minimizes hazards that may confront a barmaid without such protecting oversight." Goesaert, 335 U.S. at 466. These "moral and social" dangers, id., almost certainly referred in part to unwanted or inappropriate sexual advances or assault.

260. Int'l Únion v. Johnson Controls, Inc., 499 U.S. 187, 202 (1991) (chronicling case law demonstrating that "discrimination on the basis of sex because of safety concerns is allowed only in narrow circumstances" and that such circumstances do not include concern for women's safety alone); Green v. Waterford Bd. of Ed., 473 F.2d 629, 635 (2d Cir. 1973) (dismissing heightened safety concerns as a valid reason for discriminating against pregnant teachers); Weeks v. S. Bell Tel. \& Tel. Co., 408 F.2d 228, 235 (5th Cir. 1969) (holding that stereotypes about whether women can safely perform a job cannot form the basis for denying them that job).

261. As the hospital in E.E.O.C. v. Mercy Health Center put it, keeping men out of the obstetrics ward was not a "question [of] the credibility or reliability of a male nurse assisting a male physician during the examination of a female patient." No. CIV-80-1374-W, 1982 WL 3108, at *3 (W.D. Okla. Feb. 2 , 1982). The hospital may trust its male nurses entirely or not believe male nurses to be more sexually aggressive but still exclude them in the name of creating a perceived safe space for women who nonetheless felt unsafe around men. Id.

262. See supra Part III.B.

263. Glenn v. Brumby, 663 F.3d 1312, 1321 (11th Cir. 2011). 
"purported concern that women might object to [the plaintiff's] restroom use" was "conceivable," it was ultimately unlikely. ${ }^{264}$ The court was so skeptical of this interest, in fact, that it characterized it as "hypothesized or invented post hoc in response to litigation. ${ }^{265}$ While assumptions about the litigiousness of women faced with "unsafe" sex-integrated bathrooms might be a "conceivable" interest supporting their segregation, this interest should not hold up to intermediate scrutiny.

Once again, even if a particular safety interest in protecting women from sexual assault, or from fears of sexual assault, did not rely on stereotypes and were "important" for purposes of intermediate scrutiny, sex-segregated bathrooms would not be substantially related to forwarding these interests. In their current form, sex-segregated bathrooms are not particularly safe spaces for women. ${ }^{266}$ The point is illustrated by Meritor Savings Bank v. Vinson, where the Supreme Court found that a man following his employee into the women's bathroom and exposing himself to her contributed to a cognizable claim of sex discrimination. ${ }^{267}$ Evidently a sign with a skirt was not enough to keep determined harassers out of women's rooms. Countless news stories of women assaulted by men in women's bathrooms likewise demonstrate that such signs do not deter sexual assailants. ${ }^{268}$

In addition to posing a dubious barrier to sexual assault, sex-segregated bathrooms may actually increase the likelihood of assault. If we accept the stereotype that women are victims of sexual assault and men are perpetrators, sex segregation isolates potential victims in the women's room and indicates to male assailants where they can find them. ${ }^{269}$ Further, by decreasing the number

264. Id.

265. Id. (quoting United States v. Virginia, 518 U.S. 515, 533 (1996)).

266. Case, supra note 70 , at 220 (making "the anecdotal observation that an awful lot of male-on-female crime already takes place in the supposedly safe space of the women's room").

267. 477 U.S. 57, 60 (1987) (cited in Case, supra note 70, at 220, as evidence that women's rooms are not safe for women).

268. See, e.g., Sara J. Green, Sex Offender Hid in Golden Gardens Restroom Aiming to Rape Woman, Charges Say, SEATtle Times, Mar. 8, 2017, http://www.seattletimes.com/seattle-news/crime/sexoffender-hid-in-golden-gardens-restroom-aiming-to-rape-woman-charges-say/ [https://perma.cc /2PVS-BUEN] (describing a man who hid in the women's restroom waiting for a woman he could assault); Jorge Milian, Man Allegedly Raped Girl, 13, in Church During Funeral, PALM BEACH POST, Mar. 7, 2017, http://www.palmbeachpost.com/news/crime--law/just-man-allegedly-rapedgirl-church-during-funeral/yATo2ZNJXWBXDgaCskv4fK [https://perma.cc/NR2P-4VG7] (describing an incident of a man raping a girl in a women's restroom); Rape Reported at Viejas RV, FOX 5 SAN DIEGO, Nov. 16, 2016, http://fox5sandiego.com/2016/11/16/rape-reported-at-rv-parkon-viejas-indian-reservation [https://perma.cc/Q6WD-KH3V] (describing a man raping a woman in a bathroom stall); Man Accused of Peeping on Women in Ladies Restrooms, Attempted Rape, Koco 5 NEws, Aug. 8, 2016, http://www.koco.com/article/man-accused-of-peeping-on-women-in-ladiesrestrooms-attempted-rape/4310999 [https://perma.cc/AJJ8-M4BG] (describing a man who both "peeped" on and attempted to assault women in the women's room).

269. Overall, supra note 16, at 82 ("[A] would-be assailant has a reasonable expectation that he will find potential victims, and only potential victims, in a ladies room." (quoting Antony, supra note 92, at 5)). 
of people in any bathroom at any given time, sex-segregated bathrooms may make assault more likely by increasing the likelihood that a woman will find herself alone. ${ }^{270}$ Integrated bathrooms, by "increasing bathroom occupancy," would seem to far more successfully "reduce[] risks of predation associated with being alone and out of sight."271

Finally, compared to sex-segregated bathrooms, gender-neutral bathrooms would likely better protect against sexual assault by members of the same sex. Indeed, if we reject the stereotype that men cannot be assaulted by men, or women by women, we quickly see that sex segregation cannot be an effective solution to a general interest in preventing sexual assault. As too-frequent news stories of boys assaulted in men's bathrooms demonstrate, ${ }^{272}$ any person could derive safety benefits from a decreased chance of being alone in the bathroom. The fact that gender-neutral bathrooms would better serve the safety interests of all genders is, once again, "highly probative of the validiy"-or rather, the invalidity-of sex-segregated bathrooms. ${ }^{273}$

The substantial-relation prong of the heightened scrutiny test also undercuts the suggestion that sex-segregated bathrooms serve an interest in preventing liability or in creating perceived safe spaces for women and men. As with the privacy interest, the reliance on stereotypes about where women and men feel safe obscures possible solutions to liability or safety concerns that do not require segregation. This is perhaps most obvious in the hospital context, where providers have innovated solutions to liability and safety concerns without turning to sex segregation. The American Medical Association, for example, recommends that "chaperones" accompany physicians during sensitive examinations. ${ }^{274}$ Many hospitals have adopted such policies, obviating the need for single-sex wards. ${ }^{275}$ If institutions are worried about avoiding lawsuits or making men and women feel more safe, similar solutions are available in the

270. As Mary Anne Case observes, "the potential expected presence of both sexes in an integrated restroom could also on occasion act as a deterrent, by decreasing the likelihood a perpetrator will be alone with his intended victim and increasing the chances a bystander able and willing to offer aid will be present." Case, supra note 70, at 221.

271. Sanders \& Stryker, supra note 247247 , at 783.

272. See, e.g., Ashley Harding, Man Arrested in McDonald's Bathroom Assault, NEws 4 JAX, Aug. 22 , 2015, 8:26 AM, http://www.news4jax.com/news/man-arrested-in-mcdonalds-bathroom-assault _20151107012115973 [https://perma.cc/B76J-D5XH]; Tierra Sharae, Man Sexually Assaults 2 Boys in Westroads Mall Bathroom, Police Say, Fox42, Mar. 8, 2017, http://fox42kptm.com/news/local /police-2-boys-sexually-assaulted-by-man-in-westroads-mall-bathroom [https://perma.cc/GG85$629 \mathrm{H}]$.

273. Tuan Anh Nguyen v. I.N.S., 533 U.S. 53, 78 (2001).

274. AM. MED. ASSOC., AMA CODE OF MEDICAL ETHICS | 1.2.4 (2016), available at https://www.amaassn.org/sites/default/files/media-browser/code-of-medical-ethics-chapter-1.pdf [https://perma.cc /EA8M-AAM5].

275. Danielle Ofri, Do Patients Need a Chaperon?, N.Y. TIMES, Dec. 2, 2010, https://well.blogs.nytimes .com/2010/12/02/do-patients-need-a-chaperone/ [https://perma.cc/MF5Q-UNZ7] ("[M]ost institutions mandate that chaperons be present for rectal, pelvic and breast exams."). 
bathroom context. Best practices might include measures such as more private stalls, bathroom attendants, or diverse, gender-neutral facility options for people with different privacy desires. ${ }^{276}$

Ultimately, sex segregation is not substantially related to advancing either men's or women's actual or perceived safety and thus cannot survive intermediate scrutiny.

\section{THE NORMATIVE CASE AGAINST SEX-SEgREgATED BATHROOMS}

The sex segregation of bathrooms-if premised on the needs of biology, privacy, or safety-would likely fail intermediate scrutiny. But a straightforward application of intermediate scrutiny to sex-segregated bathrooms fails to account for some case law, including Justice Ginsburg's footnote in VMI, that suggests sex-segregated bathrooms may not be subject to that standard. Evaluating sexsegregated bathrooms under intermediate scrutiny also fails to grapple with the normative question of whether we want to eliminate sex-segregated bathrooms: if segregation provides significant enough benefits, perhaps it is not a problemnormatively, at least-if it relies on some stereotypes about men and women. This Part argues that because sex-segregated bathrooms are subordinating to women, recognizing them as unconstitutional would be both doctrinally correct and normatively good. This argument will turn on demonstrating that sexsegregated bathrooms not only rely on stereotypes but also perpetuate them in a way that harms women and facilitates inadequate fulfillment of women's needs. ${ }^{277}$

\section{A. When Separate May Be Equal: The Subordination Distinction}

Although laws requiring sex-segregated bathrooms clearly discriminate on the basis of sex and do little to support important interests, there is some language from Supreme Court opinions that suggests they nonetheless survive intermediate scrutiny. In City of Cleburne, for example, Justice Marshall seemed to look favorably upon sex-segregated bathrooms when he urged that "[a] sign that says 'men only' looks very different on a bathroom door than a courthouse door." ${ }^{278}$ More significantly, Justice Ginsburg's footnote in VMI suggests that

276. For a description of some unisex bathroom designs intended to make all people feel safer, see Lisa S. Davis, The Simple Design Solutions That Can Make Bathrooms Better-for All Genders, QUARTZ, Mar. 16, 2017, https:/qz.com/933704/how-to-design-transgender-friendly-bathrooms-that-makepeople-of-all-genders-feel-safe [https:/perma.cc/VE23-FYCG].

277. As mentioned previously, sex-segregated restrooms also do manifest harm to transgender people and to people who do not identify with either gender or sex.

278. City of Cleburne v. Cleburne Living Ctr., 473 U.S. $432,468-69$ (1985). 
sex-segregated facilities-arguably including bathrooms-are constitutionally permissible.

The significance of these comments, however, should not be overblown. They represent underdeveloped, and ultimately unpersuasive, dicta and cannot be construed as thorough defenses of sex segregation under intermediate scrutiny. This characterization is particularly appropriate given that sexsegregated bathrooms have never been directly challenged in court. The Justices' passing acceptance of sex-segregated bathrooms in fact follows a pattern similar to feminists' superficial approval of sex-segregated bathrooms during the ERA debates.

Like feminists during the ERA debates, the Justices' failure to scrutinize sexsegregated restrooms seems to reflect an assumption that this kind of discrimination is not problematic. Remember that as a litigator Justice Ginsburg suggested that "separate toilet facilities in public buildings . . . carr[y] no implication of inferiority for either sex." ${ }^{279}$ In the absence of a clear subordinating effect-or at least a lawsuit demonstrating a subordinating effect-judges such as Justice Ginsburg have not seen bathrooms as a proper target for our sex-discrimination jurisprudence.

Contrasting judicial treatment of racially segregated bathrooms with judicial treatment of sex-segregated bathrooms highlights the role of this perceived lack of subordination in judicial tolerance of sex-segregated bathrooms. While transgender litigants sometimes invoke society's intolerance of race-segregated bathrooms as evidence that transgender exclusion from bathrooms should be reviled, ${ }^{280}$ judges tend to see race segregation as different. Because "racial classifications are "obviously irrelevant and invidious," as one Maryland judge put it, "separate restroom ... facilities for blacks and whites cannot be tolerated, but such separate facilities for men and women can be justified." 281 The clear implication is that sex-segregated bathrooms are tolerable in part because, unlike racially segregated bathrooms, they are not invidious. ${ }^{282}$ Louise Antony

279. Emerson et al., supra note 78 , at 902.

280. See, e.g., Sheryl G. Stolberg et al., How the Push To Advance Bathroom Rights for Transgender Americans Reached the White House, N.Y. TIMES, May 21, 2016, http://www.nytimes.com/2016 105/22/us/transgender-bathroom-obama-schools.html [https:/perma.cc/DB7X-UD42] (quoting the mother of a transgender soldier saying "[i]t's separate but equal, so they might as well put black and white up on the bathrooms, too").

281. Burning Tree Club, Inc. v. Bainum, 305 Md. 53, 98 (1985) (quoting Goss v. Bd. of Educ., 373 U.S. $683,687(1963))$.

282. It should be noted that judges have only recently begun to view race-based distinctions as invidious. Indeed, widely accepted theories about why race-based distinctions are not invidious long justified practices of racial subjugation and segregation in this country. See, e.g., Plessy v. Ferguson, 163 U.S. 537, 550 (1896) (holding that race-based classifications were permissible as long as they were "reasonable," authorizing a judicial regime of "separate but equal" that persisted until Brown $v$. Board of Education, 347 U.S. 483 (1954)). Without wading too deeply into the fraught legal and social terrain of the race-sex analogy, widespread rejection of the once-popular, if vague, rationales behind racial segregation might lead us to look with more suspicion upon the presently popular, if vague, rationales behind sex-based segregation. For an overview of how scholars and activists have 
paraphrases scholar Richard Wassertrom as similarly urging that, while racesegregated bathrooms are subordinating, "there seems to be nothing in the [sex] segregation of bathrooms ... that evokes hierarchy, or that denigrates women." 283

If judges have merely failed to recognize sex-segregated bathrooms as subordinating, evidence that they are subordinating may push judges to apply heightened scrutiny to them. Such evidence is particularly important in the face of arguments that bathroom segregation benefits women. As the Court held in Hogan, "[i]n limited circumstances, a gender-based classification favoring one sex can be justified if it intentionally and directly assists members of the sex that is disproportionately burdened." 284 In $V M I$, Justice Ginsburg asserted that sexbased distinctions in law might be used as a kind of affirmative action to "compensate" women for past inequality or lack of opportunity. ${ }^{285}$ Many women do seem to believe that bathrooms serve this compensatory purpose, without subordinating effect. Those who oppose transgender access to bathrooms usually frame their opposition in this manner. The "radical feminists" who filed a lawsuit opposing President Obama's trans-inclusive Title IX guidance, for example, urged that the guidance ignores the social reality that women need sex-segregated spaces because they are weaker and more vulnerable to assault. ${ }^{286}$

Beyond the judicial sphere, demonstrating a subordinating effect may be essential for establishing the normative case against sex-segregated bathrooms. Women who defend sex-segregated bathrooms generally do so not in terms of their substantial relation to an important government purpose but instead in a subtler register. They defend sex-segregated bathrooms as protecting a combination of privacy, safety, biology, cultural preference, and comfort. While culture may be unimportant for purposes of heightened scrutiny, it is important to many individuals. Bathrooms are "a place to escape from a browbeating boss or importunate suitor, a place where they can cry without being seen and gossip with one another without being overheard by any man, a place where they can literally and figuratively let their hair down."287 If bathrooms are what women want, and they do not subordinate them, the argument might go, perhaps our sex discrimination jurisprudence should not invalidate them.

I will dedicate the rest of this Part to demonstrating that sex-segregated restrooms are, in fact, subordinating to all women. If segregated bathrooms

used, misused, and vigorously objected to analogies between race and sex discrimination as a means of advancing feminist legal causes, see Serena Mayeri, "A Common Fate of Discrimination": RaceGender Analogies in Legal and Historical Perspective, 110 YALE L.J. 1045 (2001).

283. Antony, supra note 92, at 4 (describing Richard Wassertrom's argument).

284. Mississippi Univ. for Women v. Hogan, 458 U.S. 718, 728 (1982) (citation omitted).

285. United States v. Virginia, 518 U.S. 515, 533 (1996).

286. Complaint, Women's Liberation Front v. U.S. Department of Justice et al., No. 1:16-cv00915 (D.N.M. Aug. 11, 2016).

287. Case, supra note 70 , at 221 . 
confer any benefits, they confer them in a manner that perpetuates the very problems they seek to solve. While many women may support sex-segregated bathrooms, or be simply indifferent towards them, sex segregation merits opposition not just for the sake of transgender and queer communities but for the sake of all women. Sex-segregated bathrooms do not merely fail to advance an important government purpose. They perpetuate invidious stereotypes-some of which hearken back to the nineteenth century-that harm women. Ultimately, this Note aims to demonstrate that all women are harmed by bathrooms' continued sex-based segregation.

\section{B. Overcoming the Privacy Objection: Sex-Segregated Bathrooms Perpetuate} Harmful Stereotypes

One need only consult differences in bathroom design between men's and women's rooms to understand how sex-segregated bathrooms both rely on and perpetuate harmful sex-based stereotypes. As we have seen, there are no "real" biological differences that justify sex-segregated bathrooms. Yet, men's and women's rooms have drastically different designs. Men's restrooms typically have a line of exposed urinals, with one or two stalls, while women's rooms comprise only enclosed stalls. Such design differences are neither natural or necessary, as countless gender-neutral bathrooms-which provide the same setup for all genders-should demonstrate. Rather, such differences both assume and perpetuate different levels of modesty for men and women.

While some might argue that different bathroom designs stem from differences in men and women's notions of privacy, it is more likely that different bathroom designs help produce the very differences in privacy tolerances they supposedly accommodate. As Ruth Barcan has suggested, "cubicles both assume and promote female modesty; they protect women from experiencing shame while also potentially contributing to the source of that shame, by enforcing women's bodily separateness from each other." ${ }^{288}$ As women's bathroom design promotes modesty, however, men's restroom design enforces a much lower level of modesty. Men and boys who wish to avoid being ostracized by peers must expect to expose their genitals—and be exposed to the genitals of other men-each time they urinate in public. ${ }^{289}$ Such differential designs teach young women that bodily exposure in the restroom is unacceptable ${ }^{290}$ but teach young men that it is expected, generating the very

\footnotetext{
288. See Barcan, supra note 116 , at 32 .
}

289. "Some boys become targets for bullying - not perceived as being 'manly' enough to stand up, show their equipment, and use a urinal-merely by entering a toilet cubicle." Anthony \& Dufresne, supra note 88 , at 55 .

290. See, e.g., ROSALIND ROSENBERG, BEYOND SEPARATE SPHERES: INTELLECTUAL ROOTS OF MODERN FEMINISM 140 (1982) ("[T]he little girl quickly learns that modesty is approved in her so she strives 
differences in privacy expectations that sex-segregated bathrooms purport to accommodate.

Such differences in privacy expectations - produced in part by the state's provision of sex-segregated bathrooms-are not innocuous. Notions that women are more modest can be traced back to the separate-spheres ideology, which sought to limit women's role in the public sphere. Women's "modesty, meekness, and patience" have long been contrasted with men's "ambition and determination" in assertions that women belong in the private sphere while men belong in the public sphere. ${ }^{291}$ An expectation that women are more modest not only limits women's sexual expression ${ }^{292}$ but also places disproportionate burdens on women to prevent harm-cdistress in the form of prim outrage or unwelcome sexual temptation for others"--by hiding and deemphasizing their own bodies. ${ }^{293}$ Such modesty carries over into other areas of life, leading women to "de-emphasize their accomplishments to a greater extent than men."294

Feminist theorists have long critiqued the privacy interest more generally, in part because they have recognized that privacy - and particularly its heightened association with women-has long been a means of perpetuating inequality. ${ }^{295}$ The very notion of privacy itself is essential to the construction of the separatespheres ideology, which relegates women to prescribed roles in the private sphere. ${ }^{296}$ Some feminist scholars have seen privacy as a means of perpetuating male dominance by implying that something about women in particular needs to be kept secret and by insulating the private abuse of women from public legal intervention. ${ }^{297}$

Nonetheless, privacy can certainly play a positive role in women's and others' lives, by promoting autonomy, liberty, and bodily integrity, both socially and legally. ${ }^{298}$ Given privacy's positive dimensions, we might be tempted to suggest that the subordinating effect of sex-segregated bathrooms could be resolved by standardizing bathroom designs and making all bathrooms more

to be modest. Unfortunately, her modesty sets her apart from men, and it prevents her from becoming inquisitive enough to consider changing herself.").

291. ROBERT B. SHOEMAKER, GENDER IN ENGLISH SOCIETY, 1650-1850: THE EMERGENCE OF SEPARATE SPHERES?, 23-25 (1998).

292. Amy Kapczynski, supra note 242 , at $1284-85$ (describing courts' reliance on "notions of bodily modesty and chastity that have long operated to deny women sexual autonomy").

293. Scott Woodcock, The Social Dimensions of Modesty, 38 CAN. J. PHIL. 1, 24 (2008).

294. Id. at 25.

295. Elizabeth M. Schneider, The Violence of Privacy, in APPLICATIONS OF FEMINIST LEGAL THEORY TO WOMEN'S LIVES: SEX, VIOLENCE, WORK, AND REPRODUCTION 388, 389 (D. Kelly Weisberg et al., eds., 1996).

296. Id. at 388 ("The traditional notion of 'separate spheres' is premised on a dichotomy between the 'private' world of family and domestic life (the 'women's' sphere), and the 'public' world of marketplace (the 'men's' sphere).").

297. MACKINNON, supra note 189, at 189-94.

298. Schneider, supra note 295 , at 390. 
private. This may seem a healthy compromise, a way of ending the disparity of modesty norms without actually integrating bathrooms. This would certainly be welcome to many men for whom a lack of bathroom privacy - based on the sexbased stereotype that men need less privacy-presents a substantial obstacle to public restroom use. ${ }^{299}$ But it would definitively fail to resolve bathrooms' subordinating effect on women.

An examination of the subordinating nature of the privacy interests supposedly threatened by more private unisex bathroom designs-but not by more private sex-segregated bathroom designs-reveals the inadequacy of the latter solution. Carefully planned and partitioned unisex bathroom designs could minimize privacy concerns related to genital exposure as effectively as sexsegregated bathrooms. They could not, however, as successfully protect the second privacy interest judges describe: preventing "injured self-esteem, humiliation and embarrassment arising out of . . . conduct of bodily functions within the perceptive range of members of the opposite sex." ${ }^{" 300}$ And this seems to be the privacy interest that proponents of sex segregation care about most. Some women fear unisex bathrooms would mean a loss of a safe space where they can conduct their "bodily functions"- do their hair, apply makeup, cry, have conversations, adjust their clothing, and use the toilet-free from the male gaze. ${ }^{301}$ While this concern is not enough to overcome heightened scrutiny, it nonetheless presents a serious critique of bathroom integration.

This well-intentioned argument, however, merely perpetuates the very harmful social stigma around women's bodies that often drives women to hide their bodily functions from men in the first place. The point is perhaps best illustrated by a number of Title VII cases in which judges have urged the necessity of excluding male employees from observing women partially because of the risk that these male employees might see their menstrual blood. ${ }^{302}$ Even the risk that a man might become aware that a woman is menstruating is unacceptable for some judges. ${ }^{303}$ While judges frame these concerns in terms of

299. Anthony \& Dufresne, supra note 88 , at $54-55$ (describing the benefits of increased privacy to men with shy-bladder syndrome).

300. In re Long, 55 Cal. App. 3d 788, 127 Cal. Rptr. 732, 735 (Ct. App. 1976).

301. See, e.g., Clara Greed, Inclusive URban Design: Public ToIlets 97 (2003).

302. One judge, for example, held that female sex is a BFOQ for a women's prison guard because " $[\mathrm{s}]$ ome inmates may wish to use the toilet upon arising ... one may find her night clothes and bedding visibly soiled from an unexpected menstrual flow and wish to clean up." Forts v. Ward, 471 F. Supp. 1095, 1101 (S.D.N.Y. 1978), vacated in part, 621 F.2d 1210 (2d Cir. 1980). The judge continued that, "[u]nder these circumstances, I deem it inappropriate for a male guard to be making the first count of the morning-with the inmates just awakened and their doors locked open." Id.

303. In one case, a judge suggested that a female prisoner's privacy would be violated if she needed to "request sanitary napkins" from a male guard. Everson v. Michigan Dept. of Corr., 391 F.3d 737, 758 (6th Cir. 2004). For a discussion of this case and its discriminatory implications, see Jami Anderson, Bodily Privacy, Toilets, and Sex Discrimination: The Problem of "Manhood" in a Women's Prison, in LADIES AND GeNTS: PUblic TOILETS AND GENDER 90 (Olga Gershenson \& Barbara Penner eds., 2009). 
protecting women's privacy, they are clearly rooted in social taboos about menstruation. Such language reflects beliefs that "menstrual blood is . . . potentially contaminating of men" and that men "must be protected even from knowing that a woman is menstruating." ${ }^{.304}$ In this case, sex segregation does not merely protect women from the "embarrassment" of being "found out" while menstruating. It also reproduces the harmful taboo it seeks to accommodate by insulating men from menstruation altogether and judicially validating men's anxiety about women's bodies. ${ }^{305}$

Taboos around menstruation are only one example of how plausibly feminist "safe space" privacy concerns help to perpetuate subordinating stereotypes about women. Ultimately, the vague "privacy" some women seek in bathroomswhether it serves them while they do their hair and makeup or engage in "unladylike" bodily functions-seems to be mostly an interest in "maintain[ing] that sense of mystery or forbiddenness about the other sex's sexuality." 306 Scholars have in fact linked sexual identity to greater shame around using the bathroom ${ }^{307}$ : in one study, heterosexual women were one of the groups most likely to be anxious about using public restrooms, in part because they feared that escaped sights or sounds were "deviation[s] from gender ideals" that would make them "unappealing" or unattractive. ${ }^{308}$ These stereotypes about what makes a woman valuable - - namely, "purity, restraint, and 'femininity" "309—can be traced back to Victorian notions of proper femininity that historically underpinned sex-segregated restrooms. ${ }^{310}$ By ensuring that men cannot see or

304. Overall, supra note 16 , at 77.

305. Further, integrated bathrooms probably would not put women at greater risk of being "found out" than anywhere else men and women spend time together-where it is also likely that a tampon will fall out of a bag or pocket, or a stain will show through clothes. Weakening the taboo around menstruation through integrated bathrooms might even relieve women of some of the significant effort involved in hiding their periods in all aspects of life, whether they no longer felt the need to hide tampons in their shirt sleeves, sneak around pharmacies with boxes of pads, or run home midday to change stained pants.

306. Richard Wasserstrom, Racism, Sexism, and Preferential Treatment: An Approach to the Topics, 24 UCLA L. REV. 581, 594 (1976).

307. At least one empirical study found that members of both sexes, regardless of gender or sexuality, are more anxious when using the bathroom in the presence of those that they are sexually attracted to but had not yet dated. Martin S. Weinberg \& Colin J. Williams, Fecal Matters: Habitus, Embodiments, and Deviance, 52 SOC. PROBS. 315, 326 (2005).

308. See id. at 327-28 (describing how heterosexual men showed the "least concern about having a bowel movement in a public restroom" while heterosexual women and non-heterosexual men demonstrated the most concern).

309. Id. at 327 (linking heterosexual women's increased anxiety over defecation to "the particular image that heterosexual women have been measured against, one that emphasizes purity, restraint, and 'femininity"').

310. See Case, supra note 70, at 221 ("The notion of women's restrooms as a haven may carry over from attitudes toward the far greater number of separate public spaces reserved in earlier centuries for women only."); Clara Greed, Taking Women's Bodily Functions into Account in Urban Planning and Policy: Public Toilets and Menstruation, 87 TOWN PLAN. REV. 505, 516 (2016). One can see a more contemporary iteration of this longstanding shame around women's bodily functions in the trope, "Everyone knows that women don't poop." Michael J. Mooney, The Queen of the Can, D 
hear when women defecate, or witness the rituals that women partake in in the restroom for "restoring one's social face,"311 sex-segregated bathrooms help perpetuate stereotypes about women's purity, ${ }^{312}$ heterosexuality, ${ }^{313}$ and difference. ${ }^{314}$

\section{Overcoming the Safety Objection: Sex-Segregated Bathrooms Perpetuate Dangers for Women}

As discussed in Part III, sex-segregated bathrooms are not substantially related to the interest of safety and may actually increase the danger of sexual assault for all genders. The persistence of sex-segregated bathrooms, however, does more damage beyond failing to serve women's safety needs. Common arguments that sex-segregated bathrooms protect women's safety both rely on and perpetuate sex-based stereotypes about women's vulnerability and men's aggression, as well as frame transgender women as potential predators rather than potential victims. These stereotypes make not only bathrooms, but also the world at large more dangerous for women, both transgender and cisgender.

Remember that when justifying sex segregation, judges assert not a generalized safety interest but instead an interest in protecting women from becoming victims of, and men from perpetrating, sexual assault. This interest aligns closely with common conservative objections to providing transgender people access to the restroom that conforms with their identity. The exclusion of transgender individuals from bathrooms stems not from a desire to discriminate, the argument goes, but from a desire to ensure women's safety. ${ }^{315}$ Along with the premise that "male" anatomy signals predation, safety-based justifications have been put forward as a plausible "feminist" objection to the integration of

MAGAZINE, Mar. 2014, https://www.dmagazine.com/publications/d-magazine $/ 2014 / \mathrm{march} /$ thequeen-of-the-can/2/ [https://perma.cc/4FSC-CV26]; see also Weinberg \& Williams, supra note 307 , at 327 (quoting a study of participants reporting views that "girls don't poop" and describing bathroom use as "not ladylike").

311. Barcan, supra note 116 , at 26

312. Cooper \& Oldenziel, supra note 212, at 28-29 (describing how "[c]leanliness has long been considered an area of female expertise and has been associated with sexual purity and virginity" and arguing that this stereotype has historically been an important basis for both racial and sex-based toilet segregation).

313. Overall, supra note 16 , at 80 (arguing that "[t]he sex segregation of toilets arguably rests upon a concept of privacy that assumes, falsely, both that heterosexuality is universal and that one needs to be private from members of the other sex but not those of one's own sex").

314. Id. at 75 ("The practice of segregating public toilets on the basis of sex is a microcosm of the operation of sex and gender norms. This practice instantiates beliefs about danger, purity, privacy, heterosexism, and the significance of biological sex differences.").

315. See, e.g., Steve Harrison, HB2, Bathroom Safety Emerges as NC Campaign Issue. What Are the Facts?, CHARLOTTE OBSERVER, Oct. 28, 2016, 5:25 PM, http://www.charlotteobserver.com/news /politics-government/articlel $11146872 \mathrm{html}$ [https://perma.cc/9GUP-V7QF] (describing supporters of a bathroom exclusion bill as primarily concerned about women and children's safety in bathrooms). 
bathrooms. ${ }^{316}$ Strict sex segregation, however, may not stop "predators intent on doing harm," and also leads to the harmful perception that a transgender woman is a "red flag[]" or potential predator. ${ }^{317}$ Safety-based objections to liberalized bathroom access thus frame transgender women (who would otherwise be put at risk in men's bathrooms) as undeserving of protection. Attempts to use such women-protective arguments to oppose transgender access to restrooms, sincere as they may be, should therefore not be entertained

In addition, a closer examination of judicial and popular reasoning about the importance of sex-segregated spaces to women's safety reveals how harmful this justification is to all women. When courts and others urge that only women are victims of and only men are perpetrators of sexual assault, they rely on assumptions that "women are by nature sexually seductive victims and that men are by nature sexual predators." ${ }^{.318}$ While it may be true that women generally are more likely to be sexually assaulted than men, ${ }^{319}$ sex segregation premised on these generalizations "foster[s] subtle social understandings that women are inherently vulnerable and in need of protection when in public." ${ }^{320}$ Further, focusing on women's victimization as "exceedingly more common and more worrisome" tends to cast women as passive and disempowered victims whose sexual virtue is essential to their worth. ${ }^{321}$ Such stereotypes about women's vulnerability and passivity should be familiar - they are the basis of a broader separate-spheres ideology that limits women's capacity to fully participate in public life. ${ }^{322}$

Further, by perpetuating social understandings about women's vulnerability and men's aggression, sex-segregated bathrooms premised on safety may actually make women more likely to experience sexual violence. Scholars have

316. See Complaint, Women's Liberation Front v. U.S. Department of Justice, No. 1:16-cv-00915 at 9 (D.N.M. August 11, 2016) (describing women's "different requirements for, and expectations of .. safety in restrooms" as a justification for keeping "men" out of women's rooms); Jeannie S. Gersen, The Transgender Bathroom Debate and the Looming Title IX Crisis, NEW YORKER, May 24, 2016, http://www.newyorker.com/news/news-desk/public-bathroom-regulations-could-createa-title-ix-crisis [https://perma.cc/4APS-QXSF] ("[T] here is also a growing sense that some females will not feel safe sharing bathrooms, shower rooms, or locker rooms with males.").

317. Kaeley Triller, $A$ Conservative Defense of Women's Rights, NAT. REV., Jan. 5, 2017, 4:00 AM, http://www.nationalreview.com/article/443534/conservatives-defend-women-oppose-transgenderbathrooms-showers [https://perma.cc/K5DY-N4SW].

318. Anderson, supra note 303, at 101.

319. Statistics About Sexual Violence, NAT. SeXUAL VIOLENCE RESOURCE CTR. 1 (2015), https:/www.nsvrc.org/sites/default/files/publications_nsvrc_factsheet_media-packet_statisticsabout-sexual-violence_0.pdf [https://perma.cc/9RPD-34NP] (describing higher incidences of sexual assault for women as compared to men).

320. Kogan, supra note 16, at 56; see also Lara Stemple \& Ilan H. Meyer, The Sexual Victimization of Men in America: New Data Challenge Old Assumptions, 104 AM. J. PUB. HEALTH e19, e19 (2014) ("[C]ontemporary depictions of sexual victimization reinforce the stereotypical sexual victimization paradigm, comprising male perpetrators and female victims.").

321. Stemple \& Meyer, supra note 320 , at e20.

322. See supra Part I.A. 
long postulated that "[e]xplanations of violence against women should center on gendered social arrangements and power," including social arrangements reinforced by the state. ${ }^{323}$ More specifically, a number of researchers and social theorists have suggested that stereotypes about women's vulnerability and men's aggression may contribute to the prevalence of man-on-woman sexual assault. ${ }^{324}$ While the link between culture and gendered violence is contested, prevalent stereotypes about male aggression likely work in combination with stereotypes about women's vulnerability and need for protection to produce gendered violence. ${ }^{325}$ Sex-segregated bathrooms, by perpetuating these very stereotypes, may thus facilitate the very violence they seek to prevent.

Finally, and perhaps most importantly, stereotype-driven beliefs that sex segregation advances safety prevent lawmakers from actually addressing sexual assault in bathrooms through more effective means than a "ladies only" sign. Indeed, it is only lawmakers' reliance on stereotypes about women's inherent vulnerability and men's inherent aggression that makes sex-segregated bathrooms, which have proven to be an ineffective safeguard for anyone's safety, appear to be a plausible solution to sexual violence. When lawmakers cast women's sexual vulnerability as a real difference, rather than a stereotype, in other words, "[t]he conditions that create women's rapability are not seen as susceptible to legal change." 326 Sex segregation becomes the legal "solution" to sexual violence, and a holistic approach to addressing gender violence appears less pressing. At the very least, states' misguided reliance on sex-based stereotypes prevents them from moving away from sex segregation and toward gender-neutral bathroom options that would better advance everyone's safety. ${ }^{327}$

\section{Separate and Unequal: Sex-Segregated Bathrooms Subordinate Women's Needs}

Beyond perpetuating stereotypes that harm women, sex-segregated bathrooms harm women by inadequately providing for their needs. Far from

323. Gwen Hunnicutt, Varieties of Patriarchy and Violence Against Women: Resurrecting "Patriarchy" as a Theoretical Tool, 15 VIOLENCE AGAINST WOMEN 553, 554 (2009).

324. See Susan Brownmiller, Against Our Will: Men, Women, and Rape 343-58 (1975) (discussing how the socialization of girls as victims and boys as perpetrators of rape contributes to the occurrence of rape); NANCY GAGER \& CATHLEEN SHURR, SEXUAL ASSAULT: CONFRONTING RAPE IN AMERICA 255 (1976) ("Men are conditioned to be rapists; women are conditioned to be victims."); Martha R. Burt, Cultural Myths and Supports for Rape, 38 J. PERSONALITY \& SOC. PSYCHOL. 217, 229 (1980) ("Rape is the logical and psychological extension of a dominantsubmissive, competitive, sex role stereotyped culture.").

325. Hunnicutt, supra note 323 , at 566 (describing scholarship supporting the proposition that notions of male "aggressiveness, male dominance and female subordination" are "bound up with a protective element in patriarchal relations," and that these work in tandem to produce violence against women).

326. MACKINNON, supra note 189, at 226.

327. Gershenson \& Penner, supra note 22, at 13 (noting the ways in which preconceptions about gender prevent us from envisioning alternatives to sex-segregated bathrooms). 
"intentionally and directly assist[ing]"328 women or "compensate[ing]" them for past inequality, ${ }^{329}$ separate bathrooms perpetuate women's inequality by disproportionately underserving them. Although public restrooms may leave much to be desired as a general matter, "public restrooms have long discriminated against certain segments of our society, especially women." 330 While men and even women tend to dismiss unequal bathroom provision as the natural result of biological or other differences-e.g., women are simply slower or more fussy in the bathroom-such reasoning from "real" difference should appear suspect at this point.

One need only observe the disproportionate lines and wait times for bathrooms at museums, parks, sporting arenas, or bars to understand the degree to which women's needs are underserved by current sex-segregated bathroom designs. ${ }^{331}$ While women may take longer to go to the bathroom, as described in Part III, this is largely due to other, social factors such as women's clothing and expectations that women should assist children or older relatives in the restroom. ${ }^{332}$ Even if women are slower "by nature," current bathroom designs exacerbate rather than accommodate this problem. Men's rooms tend to have twice the number of places to urinate as women's rooms because they contain urinals in addition to stalls. ${ }^{333}$ Further, despite the smaller volume of people that women's restrooms can serve, in many places there are still fewer or smaller women's restrooms than men's restrooms. ${ }^{334}$

A "potty parity" movement has attempted to remedy such inadequate bathroom provision for women. Some proposals include reforming building codes to require more bathroom space for women and shifting the "equality" metric from equal square footage to equal wait time for men and women. ${ }^{335}$ Yet this movement has had limited impact, and where it has been successful it has experienced backlash-largely from men. ${ }^{336}$ This is particularly ironic given that bathrooms are supposedly premised on societal concern for men and women's differing needs. Concern about biological difference disappears, it seems, when it is women who call for appropriate accommodation. This is especially true

328. Mississippi Univ. for Women v. Hogan, 458 U.S. 718, 728 (1982).

329. United States v. Virginia, 518 U.S. 515, 533 (1996) (citing Califano v. Webster, 430 U.S. 313,320 (1977) (per curiam).

330. Anthony \& Dufresne, supra note 88 , at 49.

331. Id. at 51-53.

332. See supra notes 200-203 and accompanying text.

333. Greed, supra note 205, at 118.

334. Anthony \& Dufresne, supra note 88 , at 51.

335. Id. at $56-57$.

336. Id. at 58 ("Ironically, while women have waited in long ladies' room lines for years, the passage of potty parity laws created an uproar among some men who may never have had to wait in line before."). 
when more adequate provision for women might undermine unhindered access by men.

It is clear that sex-segregated bathrooms-while purportedly benefiting women through increased privacy and safety - place disproportionate burdens on women's time, comfort, and energy. A supposedly "equal" system of sex segregation that systematically underserves women is not only constitutionally suspect but also normatively undesirable. Inadequate provision is not merely inconvenient; it enacts both practical and dignitary harms. People using the women's restroom must wait longer in line, suffer discomfort in the meantime, and even adjust their schedules to account for scarce restrooms. The harms, however, go deeper. Judith Plaskow perhaps puts it best:

Little girls crossing their legs and waiting with their mothers on endless bathroom lines absorb important lessons about what it means to live in a society in which the built environment consistently fails to reflect women's experiences and needs. In addition, girls are being conditioned to accept their peripheral status quietly and patiently. ${ }^{337}$

Sex-segregated bathrooms, which systematically underserve women's needs, instantiate and perpetuate harmful stereotypes that women's time and needs are less important. By making women uncomfortable in public, inadequate modern facilities reinforce the familiar stereotype that the public sphere is better suited for men.

Ultimately, when it comes to sex-segregated bathrooms, it seems that separate is inherently unequal. It is likely that as long as men use different restrooms from women, bathrooms will continue to inefficiently utilize space in a way that distinctly harms women. While comprehensive "potty parity" reform might ultimately reduce inequalities in bathroom access, it would still fail to eliminate the subtle messages about women's modesty, difference, and inherent vulnerability that bathroom segregation necessarily conveys. Only integrated restrooms could both resolve access inequalities and eliminate these harmful stereotypes.

\section{CONCLUSION}

In 1975, attorney Ruther Bader Ginsburg wondered "[w]ho would bring the testing lawsuit" to challenge sex-segregated bathrooms under the ERA. As the suspect history, faulty legal reasoning, and normative undesirability behind bathrooms should demonstrate, it may be time for more feminists to consider taking Justice Ginsburg's question seriously. As a matter of law, sex-segregated 
bathrooms fail to serve any important government interest. Moreover, they both rely on and perpetuate harmful stereotypes about women in a manner that should be disturbing to those interested in advancing gender equality.

Beyond the strength of the claim that sex-segregated bathrooms are unconstitutional, feminists should note that a constitutional challenge to segregation becomes less radical every day. Increasing numbers of restaurants, clubs, and art galleries now boast multi-user gender-neutral facilities. ${ }^{338}$ Genderneutral restrooms are becoming the norm on college campuses. ${ }^{339}$ Cities throughout the country have already begun to mandate the conversion of sexdesignated single-user facilities into gender-neutral ones. ${ }^{340}$ Litigants might use such local ordinances as a guide to incrementalism-even if judges might cling to the privacy and safety arguments justifying sex segregation, such arguments are at their very weakest in the context of single-user facilities.

While a legal and activist strategy for integrating restrooms is beyond the scope of this Note, one thing should be clear. Attempts to use women-protective arguments to oppose transgender individuals' access to restrooms should not be entertained. All women's activists, rather than frustrating the progress of transgender litigants with ultimately hollow concerns about safety, privacy, or biological difference, should join them in contributing to their important pursuit of gender-based equality. By bringing to the fore questions about who may access sex-segregated bathrooms, transgender and other gender-nonconforming activists have helped illuminate serious constitutional concerns about why these spaces are segregated in the first place. More importantly, they have examined the assumptions about women's difference, privacy, and safety that underlie these institutions. Such an examination can only advance the feminist cause.

338. Sanders \& Stryker, supra note 247 , at 783 (describing a gender-neutral bathroom design and its use in a number of places in the United States, including the New York Museum of Modern Art).

339. Kim Bellware, Gender-Neutral Bathrooms Are Quietly Becoming the New Thing at Colleges, HUFFPOST, July 7, 2014, http://www.huffingtonpost.com/2014/07/18/gender-neutral-bathroomscolleges_n_5597362.html.

340. See, e.g., All-Gender Restroom Ordinance FAQ, SEATTLE.GOv, https://www.seattle.gov/civilrights /programs/gender-justice-project/all-gender-restrooms/frequently-asked-questions (describing a Seattle law requiring all single-user facilities to be marked unisex by 2016); Lindsay Bramson, Austin City Council Approves Gender-Neutral Bathrooms, KXAN, Aug. 29, 2014, http://kxan.com /2014/08/28/austin-city-council-approves-gender-neutral-bathrooms (describing a similar law in Austin); Mara Gay, Gender-Neutral Bathroom Bill Approved in New York City, WALL ST. J., June 21, 2016, https://www.wsj.com/articles/gender-neutral-bathroom-bill-approved-in-new-york-city1466558172 (describing a similar law in New York City). 